\title{
SUPPLEMENT TO THE
}

Site Observational Work Plan FOR THE UMTRA PROJECT SITE At Ambrosia Lake, New Mexico

November 1995 
INTENDED FOR PUBLIC RELEASE

This report has been reproduced from the best available copy. Available in paper copy and microfiche

Number of pages in this report: 65

DOE and DOE contractors can obtain copies of this report from:

Office of Scientific and Technical Information

P.O. Box 62

Oak Ridge, TN 37831

(615) 576-8401

This report is publicly available from:

\author{
National Technical Information Service \\ Department of Commerce \\ 5285 Port Royal Road \\ Springfield, VA 22161 \\ (703) $487-4650$
}

\title{
DISCLAIMER
}

This report was prepared as an account of work sponsored by an agency of the United States Government. Neither the United States Government nor any agency thereof, nor any of their employees, makes any warranty, express or implied, or assumes any legal liability or responsibility for the accuracy, completeness, or usefulness of any information, apparatus, product, or process disclosed, or represents that its use would not infringe privately owned rights. Reference herein to any specific commercial product, process, or service by trade name, trademark, manufacturer, or otherwise does not necessarily constitute or imply its endorsement, recommendation, or favoring by the United States Government or any agency thereof. The views and opinions of authors expressed herein do not necessarily state or reflect those of the United States Government or any agency thereof. 


\section{DISCLAMMER}

Portions of this document may be illegible in electronic image products. Images are produced from the best available original document. 
REV. 0

\title{
SUPPLEMENT TO THE SITE OBSERVATIONAL WORK PLAN \\ FOR THE UMTRA PROJECT SITE \\ AT AMBROSIA LAKE, NEW MEXICO
}

November 1995

\author{
Prepared for \\ U.S. Department of Energy \\ Environmental Restoration Division \\ UMTRA Project Team \\ Albuquerque, New Mexico \\ Prepared by \\ Jacobs Engineering Group Inc. \\ Albuquerque, New Mexico
}




\section{TABLE OF CONTENTS}

Section

Page

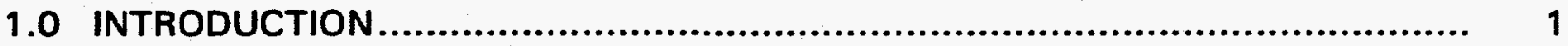

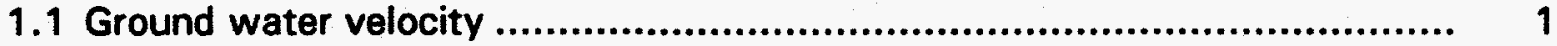

2.0 BACKGROUND GROUND WATER QUALITY ........................................... 2

2.1 Ground water quality and extent of contamination .................................. 2

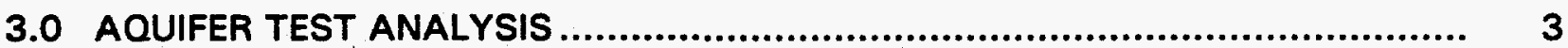

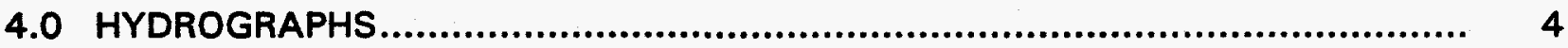

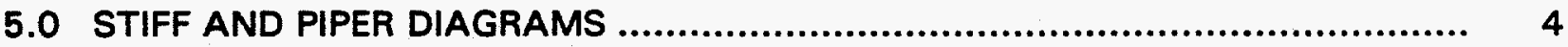

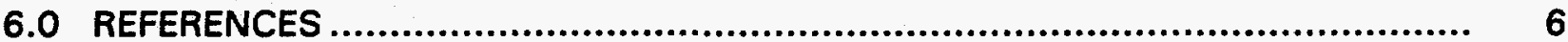

ATTACHMENT A

ATTACHMENT B

ATTACHMENT C 


\section{LIST OF FIGURES}

Figure

1 Conceptualized regional geologic cross section, Ambrosia Lake, New Mexico, site

2 Location of monitor wells and former/current site features, Ambrosia Lake, New Mexico, site

\section{LIST OF TABLES}

Table

1 Summary of hydraulic properties of hydrostratigraphic units, Ambrosia Lake, New Mexico, disposal site

2 Comparison of average linear horizontal velocities in the alluvium/weathered Mancos Shale unit estimated from hydraulic conductivities of the Ambrosia Lake, New Mexico, area....................................................................

3 Aquifer properties reanalysis using AQTESOLV software, 1989 aquifer test, Ambrosia Lake, New Mexico, site 


\section{LIST OF ACRONYMS}

Acronym

SOWP

RAP

TAC

TDS

UMTRA

\section{Definition}

site observational work plan

remedial action plan

Technical Assistance Contractor

total dissolved solids

Uranium Mill Tailings Remedial Action 


\subsection{INTRODUCTION}

The purpose of this document is to provide additional and more detailed information to supplement review of the site observational work plan (SOWP) (DOE, 1995) for the Ambrosia Lake, New Mexico, Uranium Mill Tailings Remedial Action (UMTRA) Project site. This document includes a discussion of the average linear velocity of the ground water in the alluvium and a discussion of the ground water quality of the alluvium, weathered Mancos Shale, and the Tres Hermanos-C Member of the Mancos Shale. The data from a 1989 aquifer test were analyzed using the curve-matching software AOTESOLV (Geraghty and Miller, Inc., 1995) and then compared with the original results. A hydrograph of the ground water elevations in monitoring wells screened in the alluvium is presented to show how the ground water elevations change with time. Stiff and Piper diagrams were created to describe the changes in ground water geochemistry in the alluvium/weathered Mancos Shale unit, the Tres Hermanos-C Sandstone unit, the Tres Hermanos-B Sandstone unit, and the Dakota Sandstone. Background information on other related topics such as site history, cell construction, soil characteristics, and well construction are presented in the SOWP (DOE, 1995). Figure 1 is a geologic cross section depicting the conceptual model of the hydrostratigraphy and ground water chemistry of the Ambrosia Lake site. Table 1 presents hydrogeologic information of each hydrostratigraphic unit.

\subsection{GROUND WATER VELOCITY}

Estimating the average linear velocity of the ground water in the alluvium/ weathered Mancos shale gives insight into the potential for advective contaminant transport. The equation used to estimate the average linear velocity is

$$
V=\frac{K}{n_{e}} \frac{d h}{d l}
$$

where $V$ is the average linear velocity, $K$ is the hydraulic conductivity, $\mathrm{dh} / \mathrm{dl}$ is the hydraulic gradient which is the change in head divided by the distance over which the change occurs, and $n_{e}$ is the effective porosity (Fetter, 1994). Although the hydraulic conductivity and effective porosity are consistent over time, the hydraulic gradient varies. Therefore, any estimate of velocity should be considered with respect to the gradient during the period of interest. Here, the hydraulic gradient has been calculated using water levels measured after operations had ceased at the mines in the area of the Phillips processing site.

Table 2 presents the estimated average linear horizontal velocity of the ground water in the alluvium/weathered Mancos Shale underlying the Ambrosia Lake area. The velocity was calculated using hydraulic conductivity values from aquifer pumping tests that ranged from 70 feet ( $\mathrm{ft})(21$ meters [m]) per year at the Ambrosia Lake site, to $38 \mathrm{ft}(12 \mathrm{~m})$ per year on the Quivira Mining Company property. The ground water velocity calculated from the Ambrosia Lake aquifer pumping test used a hydraulic gradient of 0.025 and an effective porosity of 
0.13, which were discussed in the remedial action plan (RAP) (DOE, 1991). The ground water velocity calculated from the Quivira Mining Company aquifer pumping test used a hydraulic gradient of 0.016 that was estimated from ground water levels taken in 1980 from monitoring wells located in the northern part of the plant property (Bostick, 1985). The effective porosity of the alluvium/weathered Mancos Shale was estimated to be 20 percent (Bostick, 1985). The hydraulic conductivity values from both aquifer pumping tests and hydraulic gradients estimated from water level measurements are appropriate for estimating horizontal ground water flow velocity.

A falling-head permeameter test was performed by Thomson and Heggen (1981) that was an estimate of the hydraulic conductivity with regard to vertical ground water flow. However, the vertical component of the velocity was not calculated because in situ vertical hydraulic gradient data were not available.

The differences between the velocity of ground water at the Ambrosia Lake site compared to the Quivira site are minor. The estimated hydraulic conductivities are very similar with some differences in hydraulic gradient and effective porosity.

\subsection{BACKGROUND GROUND WATER QUALITY}

Because there was originally no measurable water in the alluvium/weathered Mancos Shale unit or the Tres Hermanos-C Sandstone units, preoperational ground water quality data are not available for the Ambrosia Lake site. Consequently, background ground water quality in the alluvium/weathered Mancos Shale unit and the Tres Hermanos-C Sandstone units is considered to be the same as existing water quality because former mining and milling activities created the saturated conditions (Bostick, 1985). Geochemical modeling shows that the ground water within the alluvium/weathered Mancos Shale appears to be derived entirely from tailings seepage and mill-makeup water (DOE, 1991). The mill-makeup water was generated from mine pumping discharge and control of the ground water in the Westwater Canyon Member of the Morrison Formation. Details of the modeling results are presented in Table D.8.25 of the RAP (DOE, 1991). The concept of background ground water quality applies only to an aquifer that is sustained by ground water underflow from an upgradient source. Because there is no ground water underflow from an upgradient source to the uppermost aquifer at the Ambrosia Lake site, the existing water quality for the isolated pocket of saturation within the alluvium/weathered Mancos Shale unit and the basal saturation of the Tres Hermanos-C Sandstone units is defined as background.

\subsection{GROUND WATER QUALITY AND EXTENT OF CONTAMINATION}

To define the extent of ground water contamination caused by the past uranium milling at the Ambrosia Lake site, water samples were periodically collected from a U.S. Department of Energy monitor well network (Figure 2) from 1980 through 1994. 
The majority of the contaminated ground water contained in the alluvium/weathered Mancos Shale unit and Tres Hermanos-C Sandstone units in the area of the milling site was derived from water pumped from the Ann Lee Mine No. 1, Phillips mill-process waste water, and some tailings seepage. The discharge of water from the Quivira Mill to the outcrop of the Tres Hermanos-A Sandstone, Tres Hermanos-B Sandstone, and the Dakota Formation probably caused contamination of these units (Bostick, 1985). Because of the large ground water depression created by mine pumping, ground water from all overlying units will tend to migrate downward through mine shafts and vent holes into the Westwater Canyon Member of the Morrison Formation.

\subsection{AQUIFER TEST ANALYSIS}

An aquifer pumping test was performed in 1989 on well AMB01-0675 and monitored in two observation wells designated OBS-1 and OBS-2. A complete description of the well logs, including borehole description and well completion records, is provided in the SOWP (DOE, 1995). Well 675 is completed in the alluvium and in the upper $14 \mathrm{ft}(4.3 \mathrm{~m})$ of the weathered Mancos Shale. Technical Assistance Contractor (TAC) calculation set AMB-0388-15-01-01 describes the methods used in conducting the test and estimating the transmissivity and storativity (TAC, 1989). Pumping was stopped after 12 hours because the water level in the pumping well had fallen below the intake of the pump.

The data analysis software AQTESOLV developed by Geraghty and Miller, Inc. (1995), was used to analyze the data from the two observation wells and fit the best curve to the data. The time and drawdown data for each well were imported into AQTESOLV for comparison with the type curves for various aquifer conditions. The type curve used in the analysis was the Theis curve for confined aquifers (Theis, 1935). Although evidence suggests that the alluvium is unconfined, no analysis was done for unconfined ground water conditions because there were insufficient data to show the effects of delayed yield. The pumping rate at well 675 was 0.35 gallons (gal) (1.3 liters [L]) per minute. The initial saturated aquifer thickness was estimated to be $10 \mathrm{ft}(3 \mathrm{~m})$.

Aquifer test characteristics comparing the current analysis with the original analysis are presented in Table 3. The best match was obtained for data from well OBS-2 for the Theis solution (Attachment A). The Jacob (1950) solution was used for the original analysis presented in TAC calculation set AMB-03-88-15-01-01 and yielded results consistent with the Theis solution. The data from well OBS-1 yielded a poor match with the Theis theoretical curve. Early time-drawdown data resemble a curve showing the effects of partial penetration of the well while middle time-drawdown data resemble the flat segment of a curve of data showing delayed yield (Kruseman and de Ridder, 1991).

A drawdown and recovery hydrograph (Attachment A) shows that recovery at OBS-1 began to occur once pumping had stopped. In the 8 hours of recovery after pumping had stopped ground water levels rose to within $1 \mathrm{ft}(0.3 \mathrm{~m})$ of the ground water level at the beginning of pumping. Recovery data were not recorded at OBS-2 due in part to the small amount of drawdown observed during pumping. 
An aquifer pumping test was also conducted in the alluvium at the Quivira Mining Company and yielded a transmissivity ranging between 0.019 square feet $\left(\mathrm{ft}^{2}\right)(0.0018$ square meters $\left.\left[\mathrm{m}^{2}\right]\right)$ per minute to $0.023 \mathrm{ft}^{2}\left(0.0021 \mathrm{~m}^{2}\right)$ per minute and a storativity of 0.2 in the vicinity of the Quivira mill (Bostick, 1985). These values are significantly higher than those calculated from the Ambrosia Lake aquifer pumping test. However, the Quivira pumping test was performed near Arroyo del Puerto and the alluvium in this area contains a greater saturated thickness than the alluvium at the Ambrosia Lake site and may receive some recharge from along the arroyo.

\subsection{HYDROGRAPHS}

Ground water levels were periodically collected between 1985 and 1995 from up to 31 DOE wells completed in the alluvium/weathered Mancos Shale unit. Many of these wells did not show the presence of ground water following installation that indicates they are located outside the perimeter of the saturated portion of this unit. As of August 1995 only wells $674,675,781$, and 793 were producing water. In addition, water levels in some of the wells along the margins of saturation have diminished to an elevation below the base of the well screen. This indicates that the zone of saturation in the alluvium/weathered Mancos Shale unit has decreased in areal extent and declined in thickness over the 10-year period of measurement.

Selected water level data collected between 1985 and 1995 from monitor wells completed in the saturated portion of alluvium/weathered Mancos Shale unit (AMB01-0674, -0675, -0781, -0793) were retrieved from the SPEAR database (DOE, 1992) and used to create a hydrograph describing the changes in ground water elevation over the time period (Attachment B). Water levels have generally decreased in well 674 since 1988, and in well 793 since 1993. Water levels have remained relatively constant in well 781 since 1986. However, recent water level rises have occurred in well 675 , located near the southern edge of the disposal cell, that may be the result of infiltration of toe drain runoff from the disposal cell completed in June 1995.

\subsection{STIFF AND PIPER DIAGRAMS}

The most comprehensive suite of inorganic geochemical data was collected in 1991 . These data were used to create Stiff (1951) and Piper (1944) diagrams with the software PLOTCHEM (Tecsoft, Inc., 1993). These plots provide a graphical means to characterize ground water quality. Diagrams describing the ground water in the alluvium/weathered Mancos Shale unit, the Tres Hermanos-C Sandstone unit, the Tres Hermanos-B Sandstone unit, and the Dakota Sandstone were produced from the data. In addition, plots illustrating the changes in concentrations of total dissolved solids (TDS) with time and the changes in nitrate concentrations with time were produced from the data at each of these units. 
SUPPLEMENT TO THE SITE OBSERVATIONAL WORK PLAN FOR THE UMTRA PROJECT SITE AT AMBROSIA LAKE, NEW MEXICO

Of the five monitoring wells completed in the alluvium/weathered Mancos Shale unit, three wells (AMBO1-620, -674 , and -675 ) are located downgradient of the disposal cell, and two (AMB01-792 and -793) are located upgradient of the disposal cell (Figure 2).

Stiff and Piper diagrams for all wells screened in the alluvium showed similar water types (Attachment C). Wells 620, 793, and 794 exhibited calcium-sodium sulfate type waters, while wells 674 and 675 (both downgradient) exhibited sodium-sulfate type waters. The concentrations of TDS in the downgradient wells ranged from approximately 6000 to 7000 milligrams per liter $(\mathrm{mg} / \mathrm{L})$ while the concentrations in the upgradient wells were approximately $4000 \mathrm{mg} / \mathrm{L}$.

The geochemical data from four monitoring wells screened in the Tres Hermanos-C Sandstone units were also used to produce Stiff and Piper diagrams. Three of the wells (AMB01-0778, -0785, and -0786) are located upgradient from the disposal cell while one well (AMB01-0677) is located downgradient from the disposal cell (Figure 2). Well 786 is screened in the Tres Hermanos- $C_{1}$ Sandstone unit while the remaining wells are screened in the Tres Hermanos- $C_{2}$ Sandstone unit. The ground water data from 1991 were used to create these plots.

The ground water of the Tres Hermanos-C Sandstone unit was similar in water type to that of the alluvium/weathered Mancos Shale unit (Attachment C). All wells show a strong sodium-sulfate type water. The concentrations of the TDS in the upgradient wells varied between 5000 and $7000 \mathrm{mg} / \mathrm{L}$ while the concentration in the downgradient well was approximately $3500 \mathrm{mg} / \mathrm{L}$. These values support the conceptual model that the ground water from the alluvium/weathered Mancos Shale unit is recharging the Tres Hermanos-C Sandstone unit. Nitrate concentrations in well 778 range from 200 to $450 \mathrm{mg} / \mathrm{L}$; however, the other wells exhibit nitrate concentrations ranging from 0 to $50 \mathrm{mg} / \mathrm{L}$.

The ground water chemistry in the alluvium/weathered Mancos Shale unit gradually changes from a calcium-sodium sulfate type ground water to a sodium-sulfate ground water as it moves beneath the site. Sodium and sulfate were major process chemicals; thus, seepage from the mill tailings could provide the additional sodium and sulfate to the ground water. Ground water in the alluvium/weathered Mancos Shale unit flows into the Tres Hermanos-C Sandstone units in the subcrop area. The ground water at well 785 (near the subcrop contact) exhibits the highest concentrations of TDS, but concentrations decrease as the ground water travels downgradient (Figure 1). This is the expected response which is the result of the infiltration and migration of process water.

Three wells completed in the Tres Hermanos-B unit were considered for geochemical analysis. These include upgradient well AMB01-777 and downgradient wells AMB01-681 and AMB01-678 (Figure 2). Data used to produce the plots were obtained from sample collection in 1991.

The Stiff and Piper diagrams show that the ground water of the Tres Hermanos-B unit is a sodium-sulfate type water (Attachment C). Plots of TDS with time show well 678 has greater concentrations than the other two wells. Samples from well 678 also shows nitrate concentrations increasing from $500 \mathrm{mg} / \mathrm{L}$ to $3500 \mathrm{mg} / \mathrm{L}$ in the period between 1989 and 1993. 
Nitrate levels are increasing in monitor well 678, completed in the Tres Hermanos-B Sandstone $(3410 \mathrm{mg} / \mathrm{L}$ in December 1992) (DOE, 1995). This increase is not related to uranium processing at the Ambrosia Lake site because nitrate concentrations are much higher than average concentrations found in tailings pore fluids at the Ambrosia Lake site (approximately $1400 \mathrm{mg} / \mathrm{L}$ ). Furthermore, the Tres Hermanos-B Sandstone may be hydrologically isolated from the alluvium/weathered Mancos Shale unit at the site. Relatively high nitrate levels are most likely related to the nearby Quivira Mining Company tailings pile.

Well AMB01-680 is the only well at the site that is completed in the Dakota Sandstone (Figure 2). It is located south of the disposal cell. The data used to produce the plots were obtained from ground water samples collected in 1991. The Stiff and Piper diagrams generated from the geochemical data indicate a calcium-sulfate type water (Attachment C). TDS vary in concentrations from $3250 \mathrm{mg} / \mathrm{L}$ to $5500 \mathrm{mg} / \mathrm{L}$. Nitrate concentrations remain low at this well.

\subsection{REFERENCES}

Bostick, K., 1985. Ground Water Discharge Plan Analysis for Kerr-McGee Nuclear Corporation, Ambrosia Lake Uranium Mill, Quivira Mining Company, February 1985, Ground Water Sections, Ground Water Quality and Hazardous Waste Bureau, New Mexico Environmental Improvement Division, Santa Fe, New Mexico.

Brod, R. C., 1979. "Hydrogeology and Water Resources of the Ambrosia Lake-San Mateo Area, McKinley and Valencia Counties, New Mexico," master's thesis, New Mexico Institute of Mining and Technology.

Brod, R. C., and W. J. Stone, 1981. Hydrogeology of Ambrosia Lake-San Mateo Area, McKinley and Cibola Counties, New Mexico, Hydrologic Sheet 2, New Mexico Bureau of Mines and Mineral Resources.

DOE (U. S. Department of Energy), 1995. Site Observational Work Plan for the UMTRA Project Site at Ambrosia Lake, New Mexico, UMTRA-DOE/AL-62350-159, February 1995, Rev. O, prepared by the U. S. Department of Energy, UMTRA Project Office, Albuquerque Operations Office, Albuquerque, New Mexico.

DOE (U.S. Department of Energy), 1992. Software Program for Environmental Analysis and Reporting (SPEAR) System, September 1992, prepared by the U.S. Department of Energy, UMTRA Project Office, Albuquerque Operations Office, Albuquerque, New Mexico. 
DOE (U. S. Department of Energy), 1991. Remedial Action Plan and Site Conceptual Design for Stabilization of the Inactive Uranium Mill Tailings Sites at Ambrosia Lake, New Mexico, UMTRA-DOE/AL-050516.0000, November 1991, final, prepared by the U. S. Department of Energy, UMTRA Project Office, Albuquerque Operations Office, Albuquerque, New Mexico.

Fetter, C. W., 1994. Applied Hydrogeology, third edition, Macmillian College Publishing Company, New York.

Geraghty and Miller, Inc., 1995. AQTESOLV-Aquifer Test Solver, Version 2.01, Geraghty and Miller Modeling Group, Reston, VA.

Jacob, C. E., 1950. "Flow of Ground Water," in Engineering Hydraulics, H. Rouse, ed., John Wiley \& Sons, New York, pp. 321-386.

Kelly et al. (T. E. Kelly, R. L. Link, and M. R. Schipper), 1980. "Effects of Uranium Mining on Ground Water in Ambrosia Lake Area, New Mexico," in Geology and Technology of the Grants Uranium Region 1979: New Mexico Bureau of Mines and Mineral Resources, Mem. 38, pp. 313-319.

Kruseman, G. P., and N. A. de Ridder, 1991. Analysis and Evaluation of Pumping Test Data, Reprint 1991, 2nd ed. (1990), Publication 47. The Netherlands: International Institute for Land Reclamation and Improvement, $377 \mathrm{pp}$.

Piper, A. M., 1944. A Graphic Procedure in the Geochemical Interpretation of Water Analyses, American Geophysical Union, Transactions, Vol. 25, 99. 914-923.

Purtymun et al. (W. D. Purtymun, C. L. Weinke, and D. R. Dreesen), 1977. "Geology and Hydrology in the Vicinity of the Inactive Uranium Mill Tailings Pile, Ambrosia Lake, New Mexico," UC-11; Informal report LA-6839-MS, Los Alamos Scientific Laboratory of the University of California, Los Alamos, New Mexico.

Stiff, H. A., 1951. "The Interpretation of Chemical Water Analyses by Means of Patterns," Journal of Petroleum Technology, Vol. 3, pp. 15-17.

TAC (Technical Assistance Contractor), 1989. Calculation of Transmissivity and Storativity Within Alluvium/Weathered Mancos Shale Using Jacob Straight-Line Method, Calculation No. AMB-03-88-15-01-01, UPDCC File Location No. 16.19.2.7, U.S. Department of Energy, UMTRA Project Office, Albuquerque Operations Office, Albuquerque, New Mexico.

Tecsoft, Inc., 1993. PLOTCHEM, Version 6.3.

Theis, C. V., 1935. "The Lowering of the Piezometer Surface and the Rate and Discharge of a Well Using Ground Water Storage," American Geophysical Union, Transactions, Vol. 16, pp. 519-524. 
Thomson, B. M., and R. J. Heggen, 1981. "Contaminant Transport From Uranium Mill Tailings in Ambrosia Lake, New Mexico," in Proceedings of the Fourth Annual Symposium on Uranium Mill Tailings Management, 26 through 27 October 1981, Civil Engineering Department, Colorado State University, Fort Collins, Colorado. 


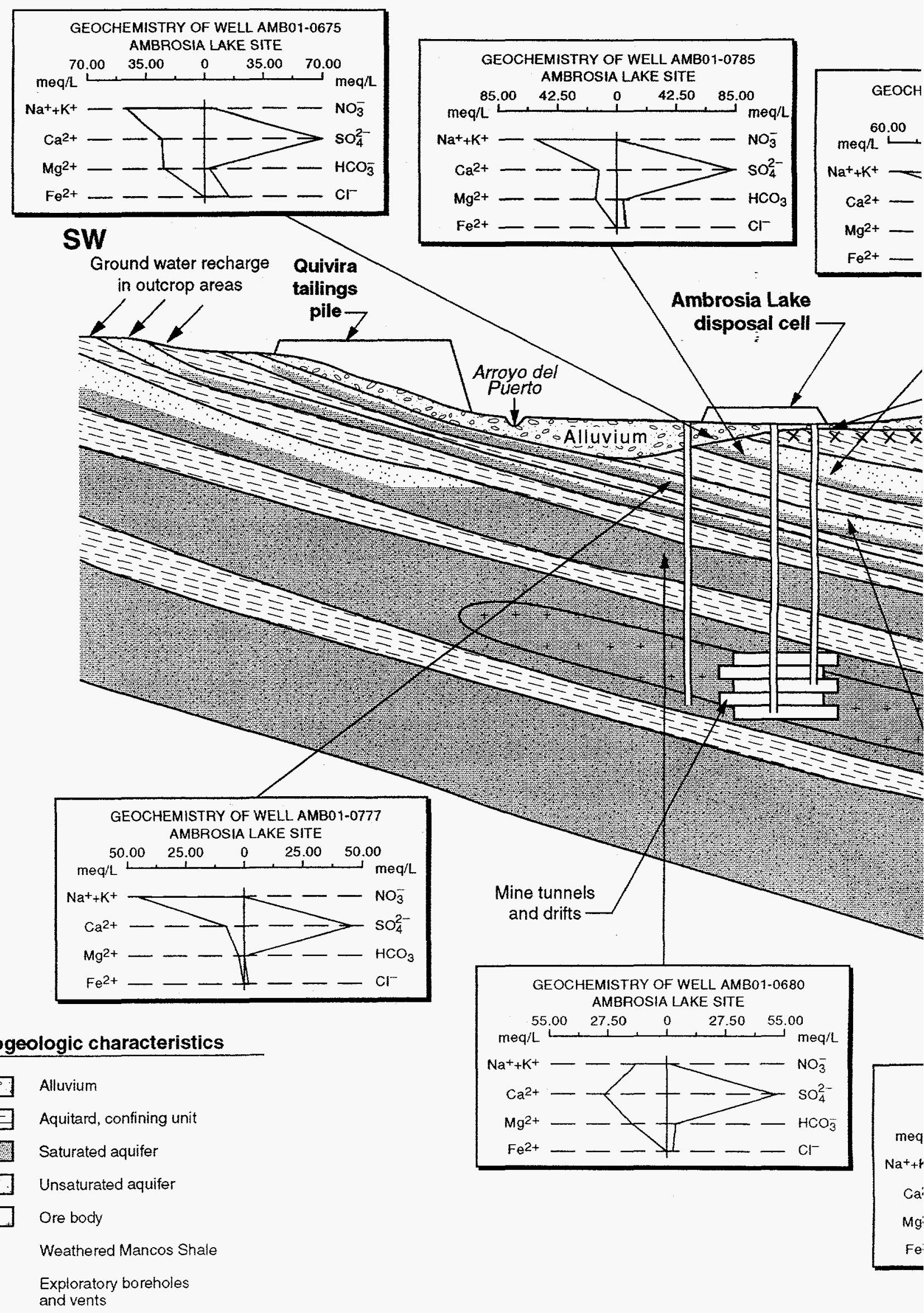




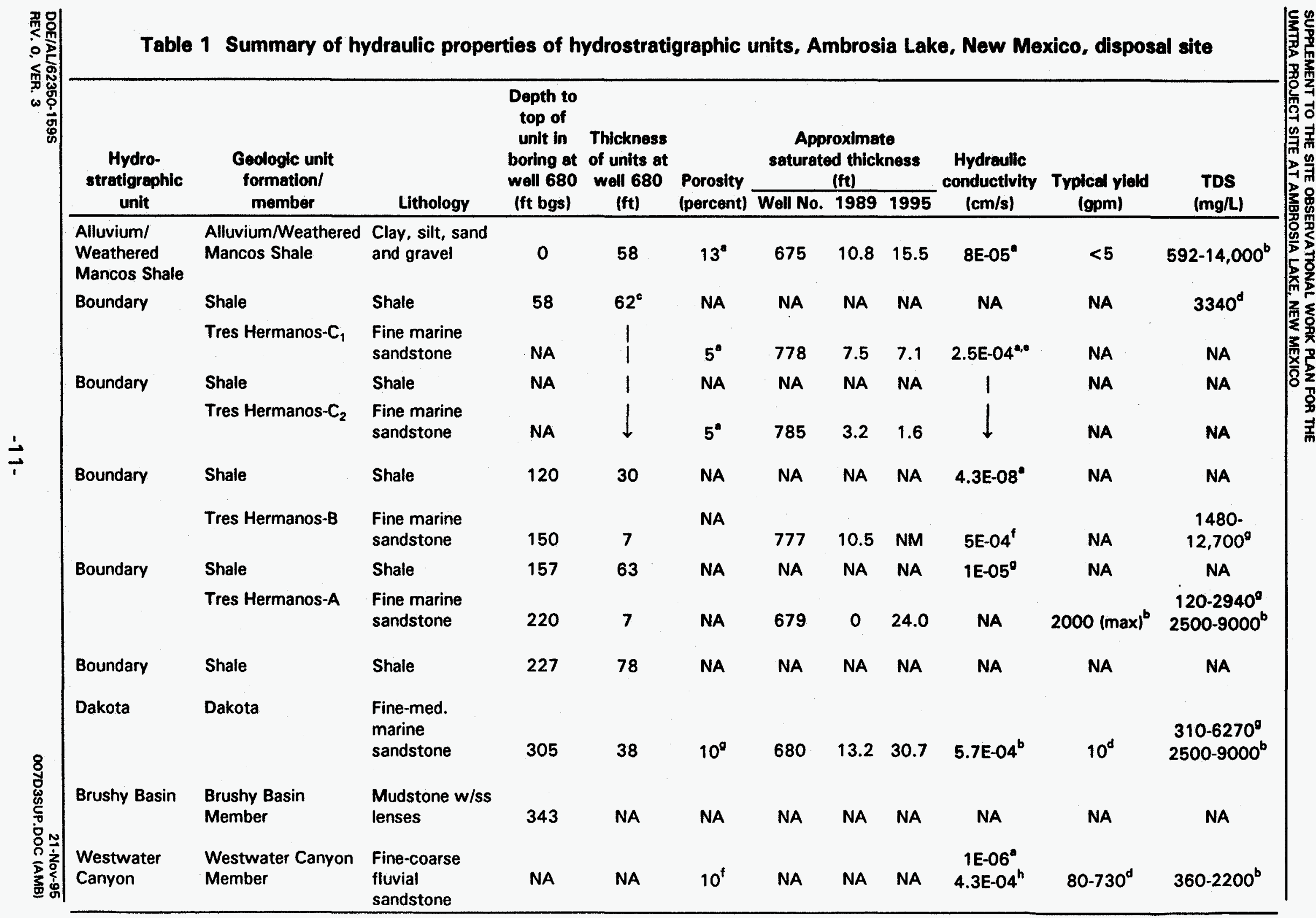


㞧哭 Table 1 Summary of hydraulic properties of hydrostratigraphic units, Ambrosia Lake, New Mexico, disposal site (Concluded)

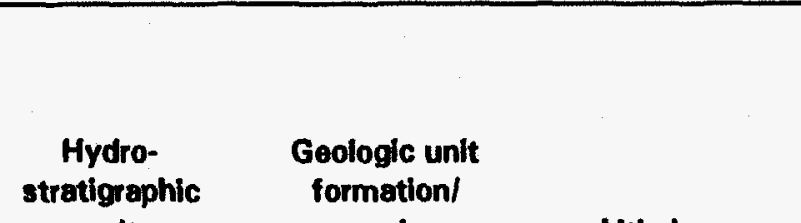

Depth to

top of

unit in Thickness

boring at of units at

well 680 well 680

stratigraphic formation

Lithology

(ft bgs)

(ft)

Approximate

saturated thickness

(ft)

Hydraulic

conductivity Typical yiold

Recapture Recapture Member Siltstone w/sh

NA

NA NA

NA NA NA

$\mathrm{cm} / \mathrm{s}$

(gpm)

(mg/L)

and ss lenses

NA

NA

NA

NA

NA

eolian

sandstone

'DOE, 1991.

bBrod and Stone, 1981.

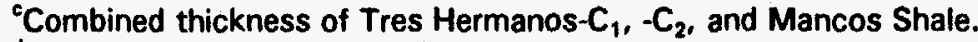

'Purtymun et al., 1977.

- Combined hydraulic conductivity of Tres Hermanos- $C_{1}$ and $-C_{2}$ Sandstone units.

'Brod, 1979.

"Bostick, 1985.

helly et al., 1980.

bgs - below ground surface.

$\mathrm{cm} / \mathrm{s}$ - centimeters per second.

gpm - gallons per minute.

NA - not available.

NM - no ground water elevations were measured.

sh - shale.

ss - sandstone. 
Table 2 Comparison of average linear horizontal velocities in the alluvium/weathered Mancos Shale unit estimated from hydraulic conductivities of the Ambrosia Lake, New Mexico, area

\begin{tabular}{|c|c|c|c|c|c|}
\hline Sample/test location & Test method & $\begin{array}{c}\text { Hydraulic } \\
\text { conductivity } \\
\text { (cm/s) }\end{array}$ & $\begin{array}{c}\text { Average } \\
\text { hydraulic } \\
\text { gradient } \\
\text { (ft/ft) }\end{array}$ & $\begin{array}{l}\text { Average } \\
\text { porosity } \\
\left(\mathrm{ft}^{3} / \mathrm{ft}^{3}\right) \\
\end{array}$ & $\begin{array}{l}\text { Average } \\
\text { linear } \\
\text { velocity } \\
\text { (ft/year) }\end{array}$ \\
\hline $\begin{array}{l}\text { Well 675, Ambrosia } \\
\text { Lake UMTRA } \\
\text { Project site }\end{array}$ & $\begin{array}{l}\text { Aquifer pumping } \\
\text { test }\end{array}$ & $0.00035^{\mathrm{a}}$ & $0.025^{a}$ & $0.13^{a}$ & 70 \\
\hline $\begin{array}{l}\text { Quivira Mining } \\
\text { Company }\end{array}$ & $\begin{array}{l}\text { Aquifer pumping } \\
\text { test }\end{array}$ & $0.0005^{b}$ & $0.016^{b}$ & $0.2^{b}$ & $38^{b}$ \\
\hline $\begin{array}{l}\text { Ambrosia Lake mining } \\
\text { district }\end{array}$ & $\begin{array}{l}\text { Falling-head } \\
\text { permeameter } \\
\text { test }\end{array}$ & $0.005^{c}$ & NA & NA & N/A \\
\hline
\end{tabular}

'DOE, 1991.

bBostick, 1985.

'Thomson and Heggen, 1981.

$\mathrm{cm} / \mathrm{s}$ - centimeters per second.

N/A - not applicable.

The following conversion factor was used to calculate the values in Table 2:

$$
V_{x}=\frac{K}{N_{e}} \frac{d h}{d l}=\left(\frac{0.00035 \mathrm{~cm} / \mathrm{sec}}{0.13 \mathrm{ft}^{3} / \mathrm{ft}^{3}}\right)\left(\frac{0.025 \mathrm{ft}}{\mathrm{ft}}\right)\left(\frac{0.0328 \mathrm{ft}}{\mathrm{cm}}\right)\left(\frac{3.17 \mathrm{E} 07 \mathrm{sec}}{\mathrm{yr}}\right)=70 \mathrm{ft} / \mathrm{yr}
$$




\section{Figure 2}

\section{Location of Monitor Wells and Former/Current Site Features}

\section{Ambrosia Lake, New Mexico, Site}

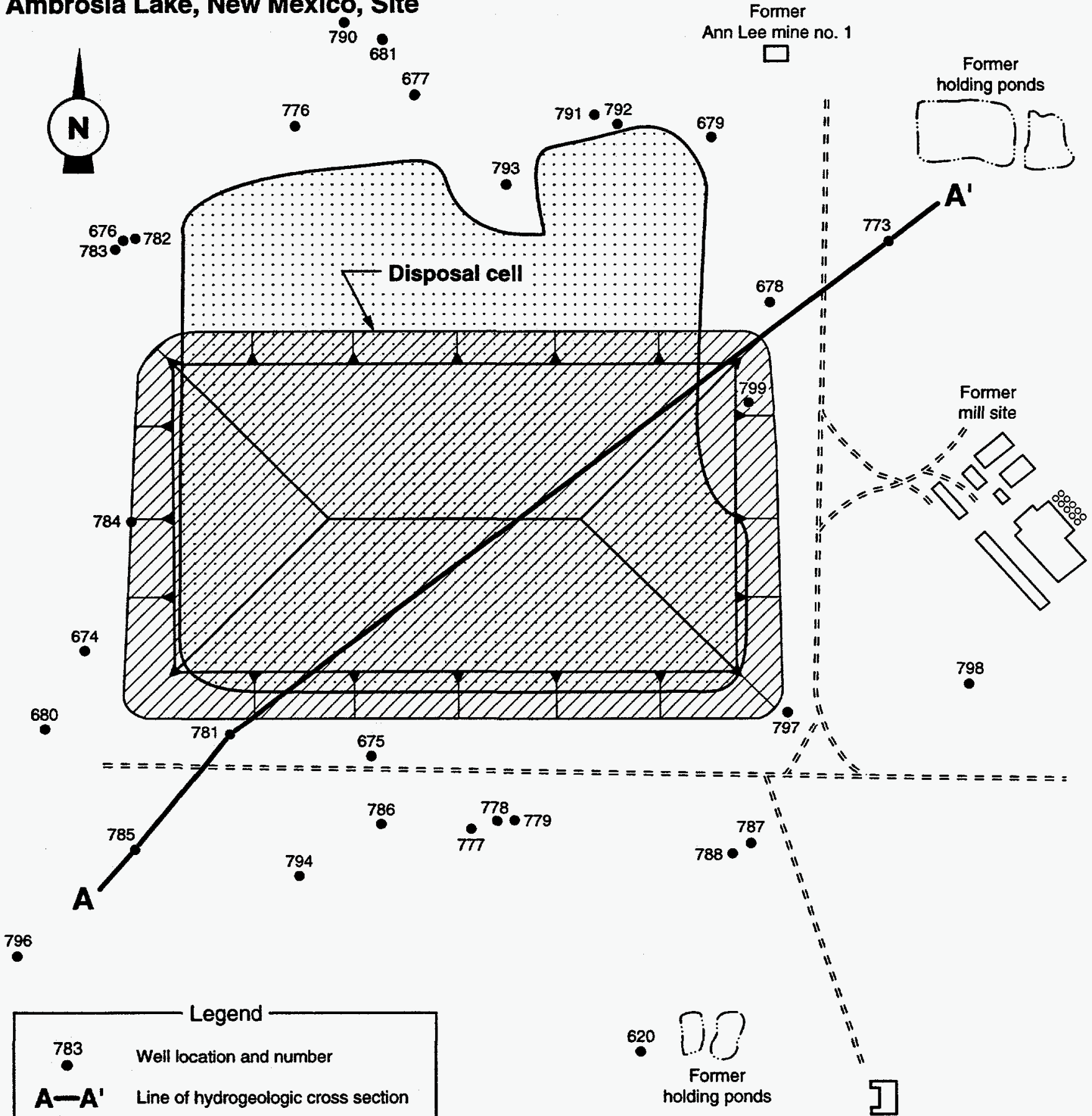

Indicates extent of tailings pile prior
to remedial action
$:===\quad$ Dirt road

holding ponds

Sec. 33 mine

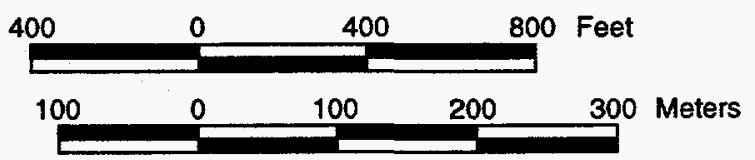

Modified from DOE, 1991. 
Table 3 Aquifer properties reanalysis using AQTESOLV software, 1989 aquifer test, Ambrosia Lake, New Mexico, site

\begin{tabular}{lc}
\hline \multicolumn{1}{c}{ Parameter } & OBS-2 \\
\hline Distance from well 675, $\mathrm{ft}$ & 29.5 \\
Saturated thickness, $\mathrm{ft}$ & 10 \\
Theis method & \\
(Confined, nonleaky aquifer analysis) & \\
$\mathrm{T}, \mathrm{ft}^{2} / \mathrm{min}$ & 0.0027 \\
$\mathrm{~S}$ & 0.005 \\
Jacob method & \\
(Confined, nonleaky aquifer analysis) & \\
$\mathrm{T}, \mathrm{ft}^{2}$ /min & 0.0065 \\
$\mathrm{~S}$ & 0.0004 \\
\hline $\mathrm{ft}^{2} /$ min - square feet per minute. \\
$\mathrm{T}$ - transmissivity. \\
$\mathrm{S}$ - storativity.
\end{tabular}




\section{ATTACHMENT A}




\section{TABLE OF CONTENTS}

Section

Page

Type curves for aquifer test analysis............................................................. A-1

Data output from AQTESOLV..................................................................... A-3

Drawdown and recovery data for OBS-1, Ambrosia Lake site ............................. A-7 


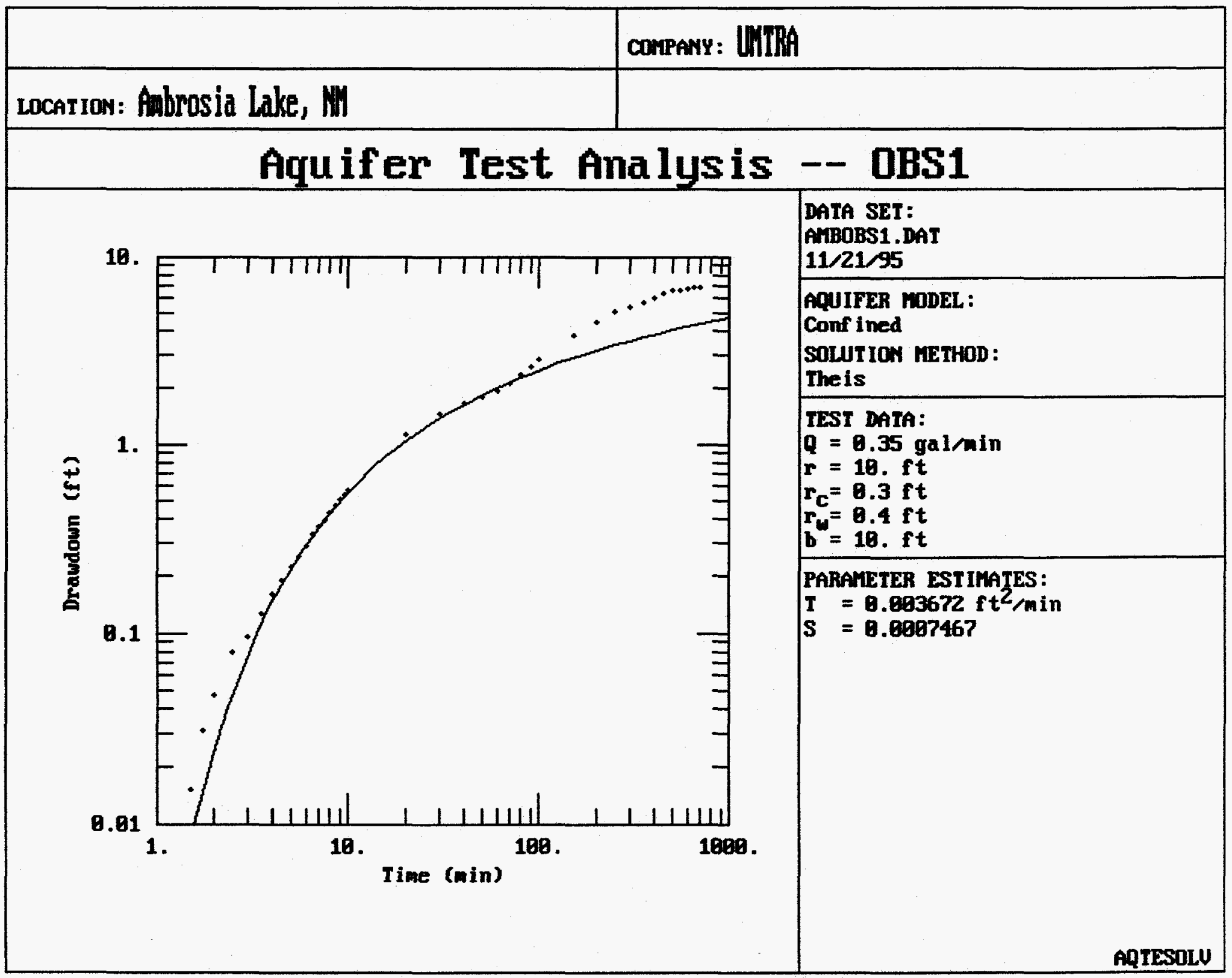




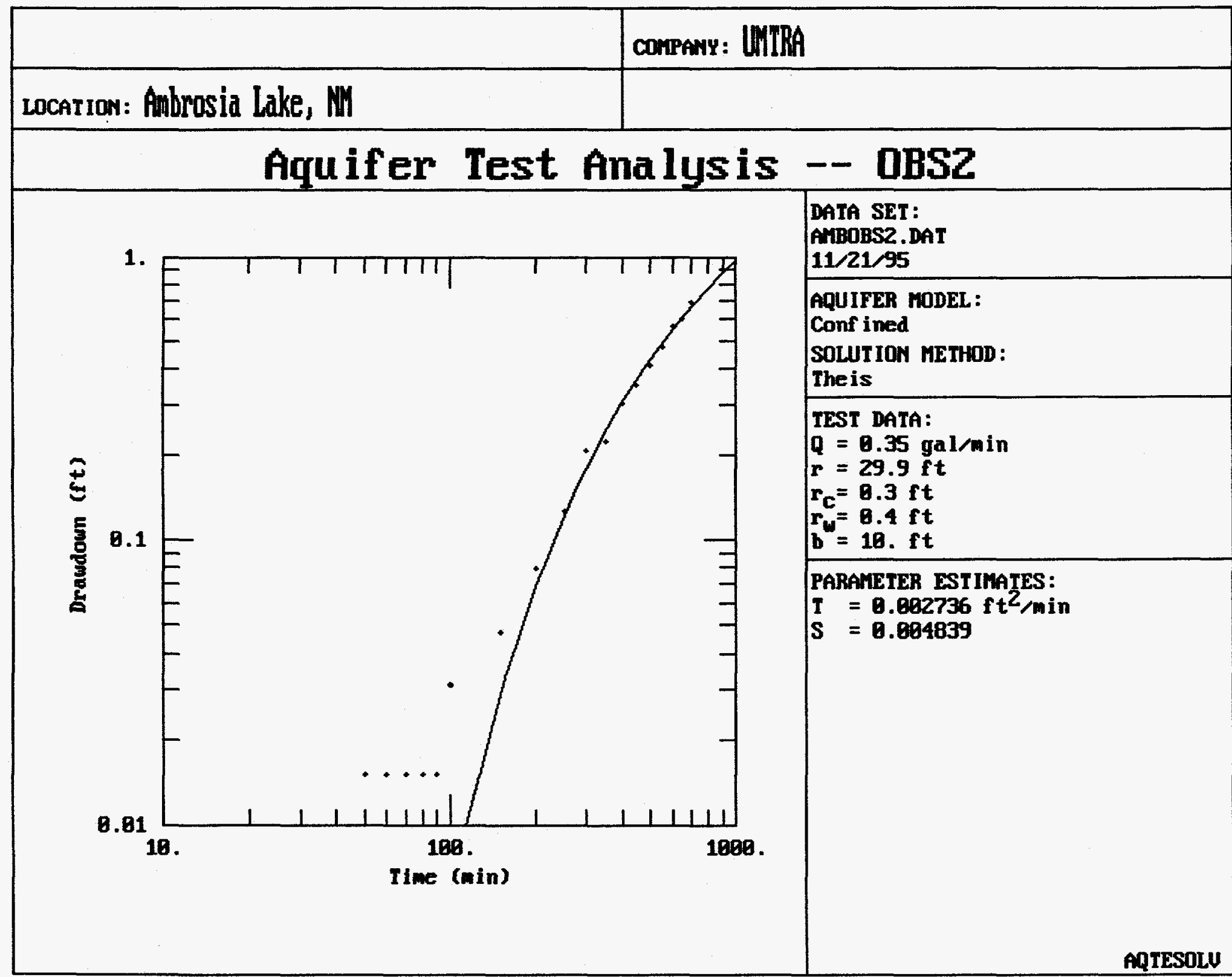




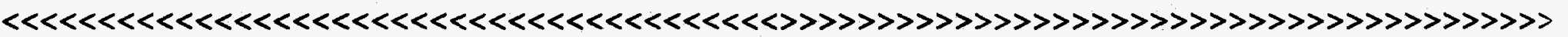

$$
\begin{aligned}
& \text { A Q T E S O I V R E S U I T S } \\
& \text { Version 2.01 } \\
& \text { Developed by Glenn M: Duffield } \\
& \text { (c) 1988-1995 Geraghty \& Miller, Inc. }
\end{aligned}
$$

$11 / 21 / 95$

$14: 31: 28$

\section{TEST DESCRIPTION}

Data set............. AMBOBS2. DAT

output file.......... AMBOBS2.OUT

Data set title..... Aquifer Test Analysis -- OBS2

Company........... UNTRA

Location............ Ambrosia Lake, NM

Test well.......... Well 675

Obs. well.......... Well OBS2

Units of Measurement

Length........ ft

Time.......... min

Pumping rate.... gal/min

Pumping Well Data

Well No. 1

Well identification........... Well 675

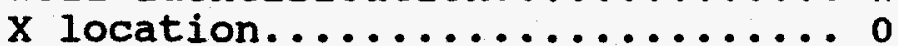

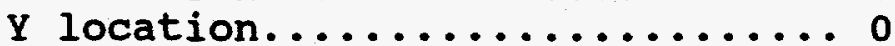

Casing radius.................... 0.3

Wellbore radius............... 0.4

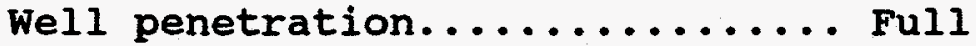

Number of pumping periods....... 1

Period Pumping Rate

$----1--------$

1

0.35

Observation Well/Piezometer Data

Well identification........... Well OBs2

x location................. 29.9

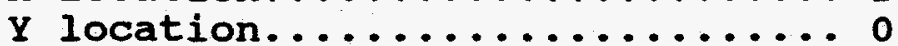

Distance from pumping well \#1...2 29.9

Well penetration............. Full

No. of observations........... 18

ANALYTICAL METHOD

Theis (Confined Aquifer)

Fully Penetrating Wells 


$\begin{array}{lll}\text { Estimate } & \text { Std. Error } \\ \mathrm{T}= & 2.7359 \mathrm{E}-003+/- & 2.0691 \mathrm{E}-004 \\ \mathrm{~S} & =4.8 \mathrm{ft}^{\wedge} 2 / \mathrm{min}\end{array}$

ANALYSIS OF MODEL RESIDUALS

residual = observed - calculated

weighted residual $=$ residual $*$ weight

Weighted Residual statistics:

Number of residuals............ 18

Number of estimated parameters.... 2

Degrees of freedom............ 16

Residual mean................. 0.006519

Residual standard deviation...... 0.01701

Residual variance............. 0.0002893

Model Residuals:

\begin{tabular}{crrrr} 
Time & Observed & Calculated & Residual & Weight \\
\hline 50 & 0.015 & $5.6863 \mathrm{E}-005$ & 0.014943 & 1 \\
60 & 0.015 & 0.00025021 & 0.01475 & 1 \\
70 & 0.015 & 0.00073513 & 0.014265 & 1 \\
80 & 0.015 & 0.0016733 & 0.013327 & 1 \\
90 & 0.015 & 0.0032069 & 0.011793 & 1 \\
100 & 0.031 & 0.0054421 & 0.025558 & 1 \\
150 & 0.047 & 0.028385 & 0.018615 & 1 \\
200 & 0.079 & 0.068731 & 0.010269 & 1 \\
250 & 0.127 & 0.1207 & 0.0062951 & 1 \\
300 & 0.206 & 0.17933 & 0.026667 & 1 \\
350 & 0.222 & 0.24128 & -0.019281 & 1 \\
400 & 0.302 & 0.30446 & -0.0024568 & 1 \\
450 & 0.35 & 0.36758 & -0.017582 & 1 \\
500 & 0.413 & 0.42989 & -0.016885 & 1 \\
550 & 0.477 & 0.49091 & -0.013913 & 1 \\
600 & 0.566 & 0.55041 & 0.015591 & 1 \\
650 & 0.604 & 0.60824 & -0.0042436 & 1 \\
700 & 0.684 & 0.66437 & 0.019635 & 1
\end{tabular}

RESULTS FROM VISUAL CURVE MATCHING

VISUAL MATCH PARAMETER ESTIMATES

Estimate

$T=2.7359 \mathrm{E}-003 \mathrm{ft} 2 / \mathrm{min}$
$S=4.8394 \mathrm{E}-003$

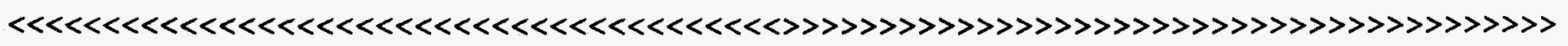




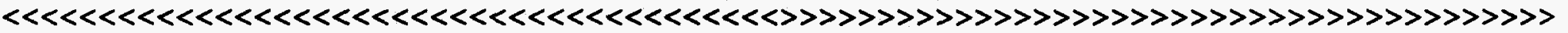
A Q T E S O L V RESULT S
Version 2.01
Developed by Glenn M. Duffield
(c) 1988-1995 Geraghty \& Miller, Inc.

$11 / 21 / 95$

$14: 34: 43$

TEST DESCRIPTION

Data set........... AMBOBS1.DAT

output file........ AMBOBS1.OUT

Data set title..... Aquifer Test Analysis -- OBS1

Company.......... UMTRA

Location.......... Ambrosia Lake, NM

Test well.......... Well 675

Obs. well.......... Well OBS1

Units of Measurement

Length......... ft

Time.......... min

Pumping rate.... gal/min

Pumping Well Data

Well No. 1

Well identification........... Well 675

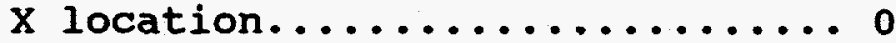

Y location..................

Casing radius............... 0.3

Wellbore radius.............. 0.4

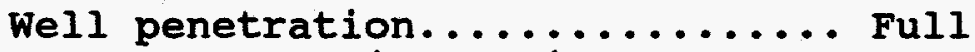

Number of pumping periods....... 1

Period Pumping Rate

- - - - - - - - - - - - -

$1 \quad 0.35$

Observation Well/Piezometer Data

Well identification............ OBS1

x location................. 10

Y location.....................

Distance from pumping well \#1... 10

Well penetration.............. Full

No. of observations..........4 40

Theis (Confined Aquifer)

Fully Penetrating Wells

\section{RESULTS FROM STATISTICAL CURVE MATCHING}

STATISTICAL MATCH PARAMETER ESTIMATES 
Estimate

$T=1.7251 \mathrm{E}-003+/-$

$S=1.0547 \mathrm{E}-003+1-$
Std. Error

6.0460E-005 ft^2/min

$5.7654 \mathrm{E}-005$

\section{ANALYSIS OF MODEL RESIDUALS}

residual = observed - calculated

weighted residual $=$ residual * weight

Weighted Residual statistics:

Number of residuals...........40 40

Number of estimated parameters.... 2

Degrees of freedom............ 38

Residual mean............... 0.08722

Residual standard deviation...... 0.2396

Residual variance............. 0.05741

Model Residuals:

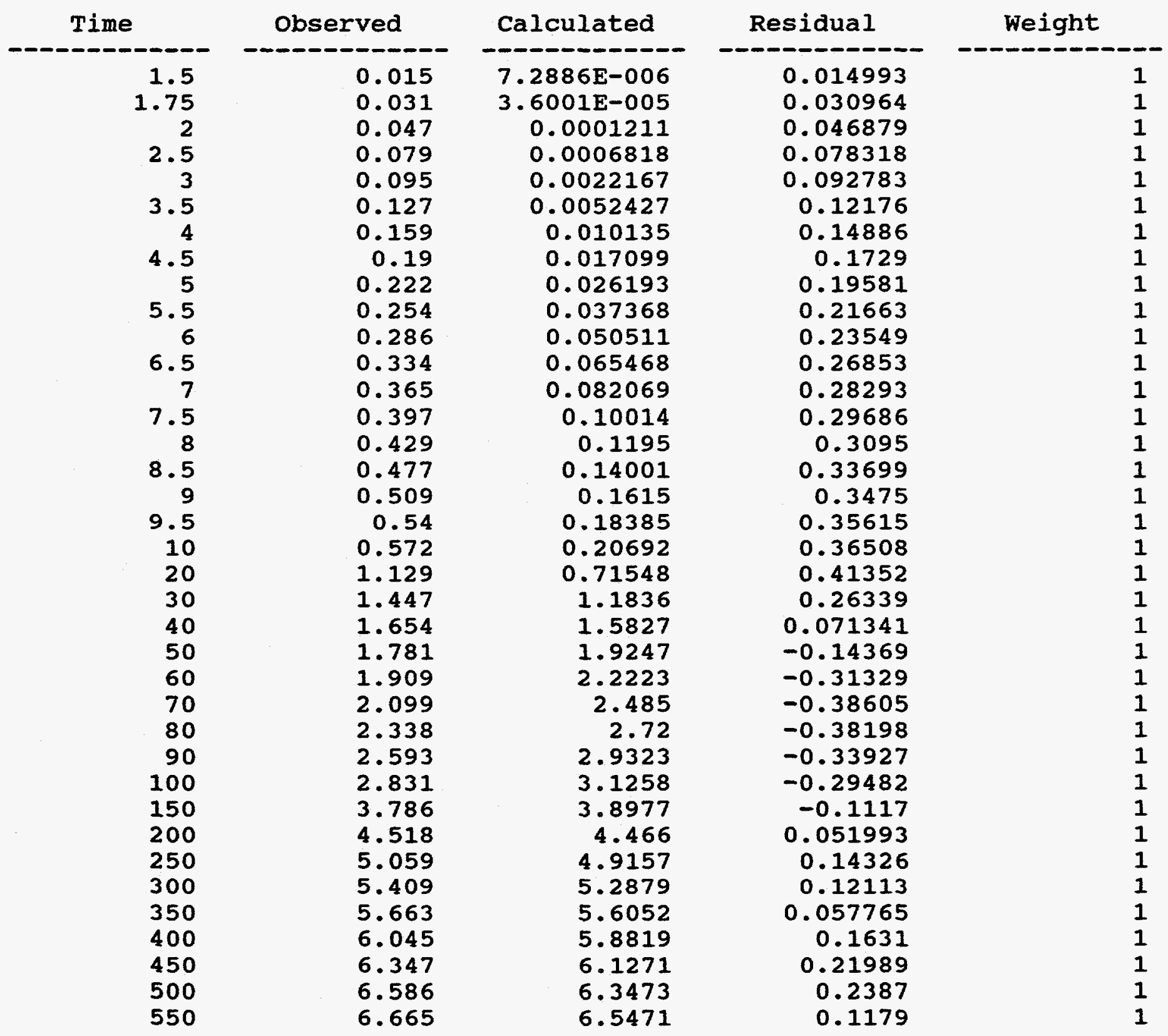




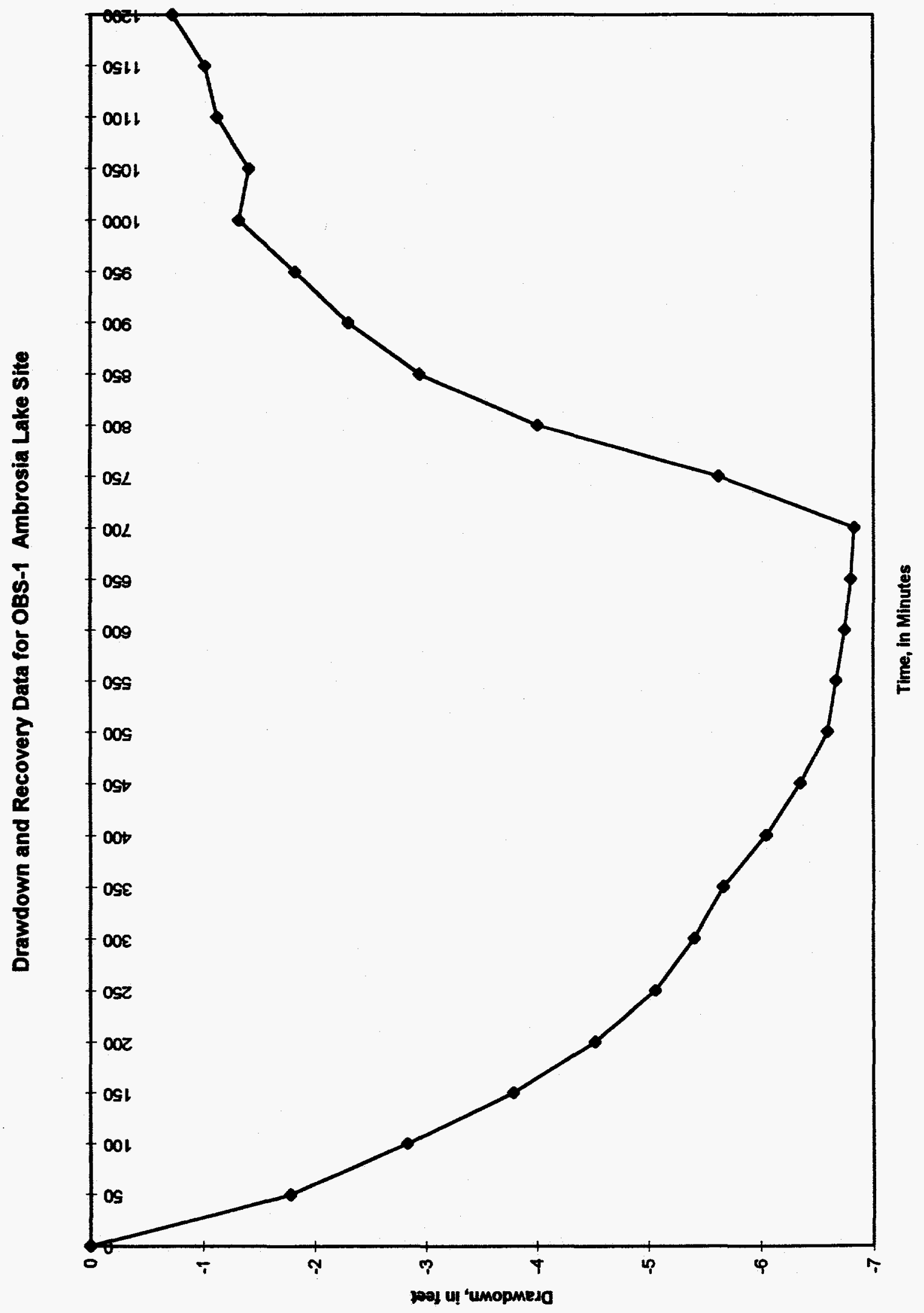

A-7 
ATTACHMENT B 


\section{TABLE OF CONTENTS}

\section{Section}

\section{Page}

Hydrograph showing ground water elevation trends in monitor wells completed in the alluvium/weathered Mancos Shale hydrostratigraphic unit.. B-1

Static ground water levels (from SPEAR database) 
Hydrograph Showing Ground Water Elevation Trends in Monitor Wells Completed in the Alluvium/Weathered Mancos Shale Hydrostratigraphic Unit
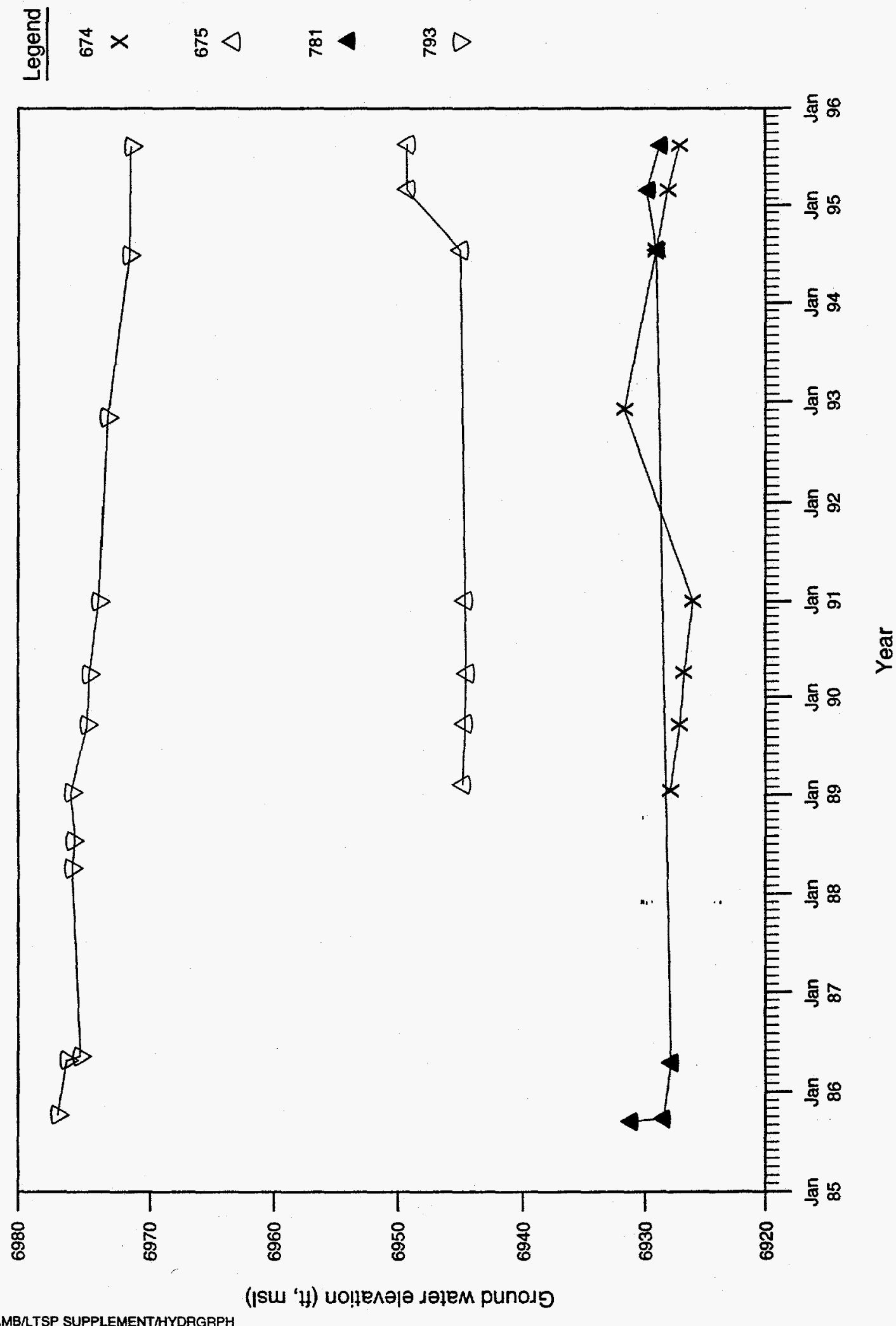
Static Ground Water Levels

Site: AMB01 Ambrosia Lake

\begin{tabular}{|c|c|c|c|c|c|c|c|c|c|c|c|}
\hline $\begin{array}{l}\text { Location } \\
\text { ID }\end{array}$ & \begin{tabular}{|c|} 
North \\
Coordinate \\
(ft)
\end{tabular} & \begin{tabular}{|c|} 
East \\
Coordinate \\
(ft)
\end{tabular} & \begin{tabular}{|c|}
$\begin{array}{c}\text { Formation } \\
\text { of } \\
\text { Completion }\end{array}$ \\
\end{tabular} & $\begin{array}{l}\text { Flow } \\
\text { Code }\end{array}$ & $\begin{array}{c}\text { Casing } \\
\text { Elevation } \\
\text { (ft, NGVD) }\end{array}$ & $\begin{array}{c}\text { Ground } \\
\text { Elevation } \\
\text { (ft, NGVD) }\end{array}$ & Log Date & Log Time & $\begin{array}{c}\text { Depth from } \\
\text { Top of } \\
\text { Casing }(\mathrm{ft})\end{array}$ & $\begin{array}{c}\text { Depth from } \\
\text { Ground } \\
\text { (ft) }\end{array}$ & $\begin{array}{c}\text { Ground-water } \\
\text { elevation } \\
\text { (ft, NGVD) }\end{array}$ \\
\hline 674 & 53795.77 & 58785.81 & $\mathrm{Al}$ & $\bar{D}$ & 6973.3 & 6972.92 & $\begin{array}{c}2 / 1 / 89 \\
9 / 14 / 89 \\
4 / 6 / 90 \\
1 / 9 / 91 \\
12 / 3 / 92 \\
7 / 13 / 94 \\
3 / 7 / 95 \\
8 / 22 / 95\end{array}$ & $\begin{array}{l}14: 00 \\
15: 30 \\
12: 00 \\
16: 15 \\
13: 20 \\
14: 32 \\
15: 11 \\
11: 38\end{array}$ & $\begin{array}{l}45.65 \\
46.32 \\
46.86 \\
47.57 \\
41.95 \\
44.6 \\
45.55 \\
46.46\end{array}$ & $\begin{array}{l}45.27 \\
45.94 \\
46.48 \\
47.19 \\
41.57 \\
44.22 \\
45.17 \\
46.08\end{array}$ & $\begin{array}{c}6927.65 \\
6926.98 \\
6926.44 \\
6925.73 \\
6931.35 \\
6928.7 \\
6927.75 \\
6926.84\end{array}$ \\
\hline 675 & 53182.54 & 59915.9 & $\mathbf{K M}$ & $\overline{\mathrm{D}}$ & 6966.65 & 6965.96 & $\begin{array}{c}2 / 2 / 89 \\
9 / 13 / 89 \\
4 / 11 / 90 \\
1 / 16 / 91 \\
7 / 13 / 94 \\
3 / 7 / 95 \\
8 / 22 / 95\end{array}$ & $\begin{array}{l}8: 25 \\
12: 10 \\
12: 30 \\
13: 30 \\
11: 03 \\
16: 40 \\
13: 45 \\
\end{array}$ & $\begin{array}{c}22.2 \\
22.35 \\
22.58 \\
22.54 \\
22.35 \\
17.81 \\
17.77\end{array}$ & $\begin{array}{l}21.51 \\
21.66 \\
21.89 \\
21.85 \\
21.66 \\
17.12 \\
17.08\end{array}$ & $\begin{array}{c}6944.45 \\
6944.3 \\
6944.07 \\
6944.11 \\
6944.3 \\
6948.84 \\
6948.88 \\
\end{array}$ \\
\hline 793 & 55493 & 60225.7 & $\overline{\mathrm{Al}}$ & $\bar{U}$ & 6998.6 & 6996.6 & $\begin{array}{c}10 / 8 / 85 \\
4 / 29 / 86 \\
5 / 17 / 86 \\
4 / 4 / 88\end{array}$ & $\begin{array}{c}14: 18 \\
11: 35 \\
9: 50 \\
15: 10\end{array}$ & \begin{tabular}{c|}
21.4 \\
22.03 \\
23.38 \\
22.49
\end{tabular} & $\begin{array}{c}19.4 \\
20.03 \\
21.38 \\
20.49\end{array}$ & $\begin{array}{c}6977.2 \\
6976.57 \\
6975.22 \\
6976.11\end{array}$ \\
\hline
\end{tabular}




\begin{tabular}{|c|c|c|c|c|c|c|c|c|c|c|c|}
\hline $\begin{array}{l}\text { Location } \\
\text { ID }\end{array}$ & \begin{tabular}{|c|} 
North \\
Coordinate \\
(ft)
\end{tabular} & $\begin{array}{c}\text { East } \\
\text { Coordinate } \\
\text { (ft) }\end{array}$ & $\begin{array}{c}\text { Formation } \\
\text { of } \\
\text { Completion }\end{array}$ & $\begin{array}{l}\text { Flow } \\
\text { Code }\end{array}$ & $\begin{array}{c}\text { Casing } \\
\text { Elevation } \\
\text { (ft, NGVD) }\end{array}$ & $\begin{array}{c}\text { Ground } \\
\text { Elevation } \\
\text { (ft, NGVD) }\end{array}$ & Log Date & Log Time & $\begin{array}{l}\text { Depth from } \\
\text { Top of } \\
\text { Casing (ft) }\end{array}$ & $\begin{array}{l}\text { Depth from } \\
\text { Ground } \\
\text { (ft) }\end{array}$ & $\begin{array}{l}\text { Ground-water } \\
\text { elevation } \\
\text { (ft, NGVD) }\end{array}$ \\
\hline 793 & 55493 & 60225.7 & Al & $\mathrm{U}$ & 6993.63 (a) & 6996.6 & $\begin{array}{c}7 / 12 / 88 \\
1 / 6 / 89 \\
9 / 13 / 89 \\
3 / 29 / 90 \\
1 / 9 / 91 \\
11 / 24 / 92 \\
7 / 13 / 94 \\
8 / 22 / 95\end{array}$ & $\begin{array}{c}13: 45 \\
13: 44 \\
15: 50 \\
17: 50 \\
13: 00 \\
8: 55 \\
14: 51 \\
12: 21\end{array}$ & $\begin{array}{c}22.72 \\
22.7 \\
23.74 \\
24.05 \\
24.76 \\
25.71 \\
27.55 \\
22.72 \\
\end{array}$ & \begin{tabular}{c|}
20.72 \\
20.7 \\
21.74 \\
22.05 \\
22.76 \\
23.71 \\
25.55 \\
20.72 \\
\end{tabular} & \begin{tabular}{|c|}
6975.88 \\
6975.9 \\
6974.86 \\
6974.55 \\
6973.84 \\
6972.89 \\
6971.05 \\
$6970.91(a)$ \\
\end{tabular} \\
\hline
\end{tabular}

Formation of Completion Code:

Al - Alluvium

KM - Mancos Shale

(a) revised data based on modification of monitor well casing elevation 
ATTACHMENT C 
TABLE OF CONTENTS

Section

Page

Piper diagrams describing the ground water chemistry of the alluvium ................... C-1

Stiff diagrams describing the ground water chemistry of the alluvium ..................... C-2

Total dissolved solids vs. time in alluvial monitoring wells ................................... C-4

Nitrate vs. time in alluvial monitoring wells ..................................................... C-5

Piper diagrams describing the ground water chemistry of the Tres Hermanos-C......... C-6

Stiff diagrams describing the ground water chemistry of the Tres Hermanos-C.......... C-7

Total dissolved solids vs. time in monitoring wells screened in the Tres Hermanos-C... C-8

Nitrate vs. time in monitoring wells screened in the Tres Hermanos-C .................... C-9

Piper diagrams describing the ground water chemistry of the Tres Hermanos-B ......... C-10

Stiff diagrams describing the ground water chemistry of the Tres Hermanos-B ........... C-11

Total dissolved solids vs. time in monitoring wells of the Tres Hermanos-B .............. C-12

Nitrate vs. time in monitoring wells of the Tres Hermanos-B ............................. C-13

Piper diagrams describing the ground water chemistry of the Dakota sandstone ......... C-14

Stiff diagrams describing the ground water chemistry of the Dakota sandstone ......... C-15

Total dissolved solids vs. time in monitoring well screened in the Dakota sandstone ... C-16

Nitrate vs. time in monitoring well screened in the Dakota sandstone ..................... C-17 


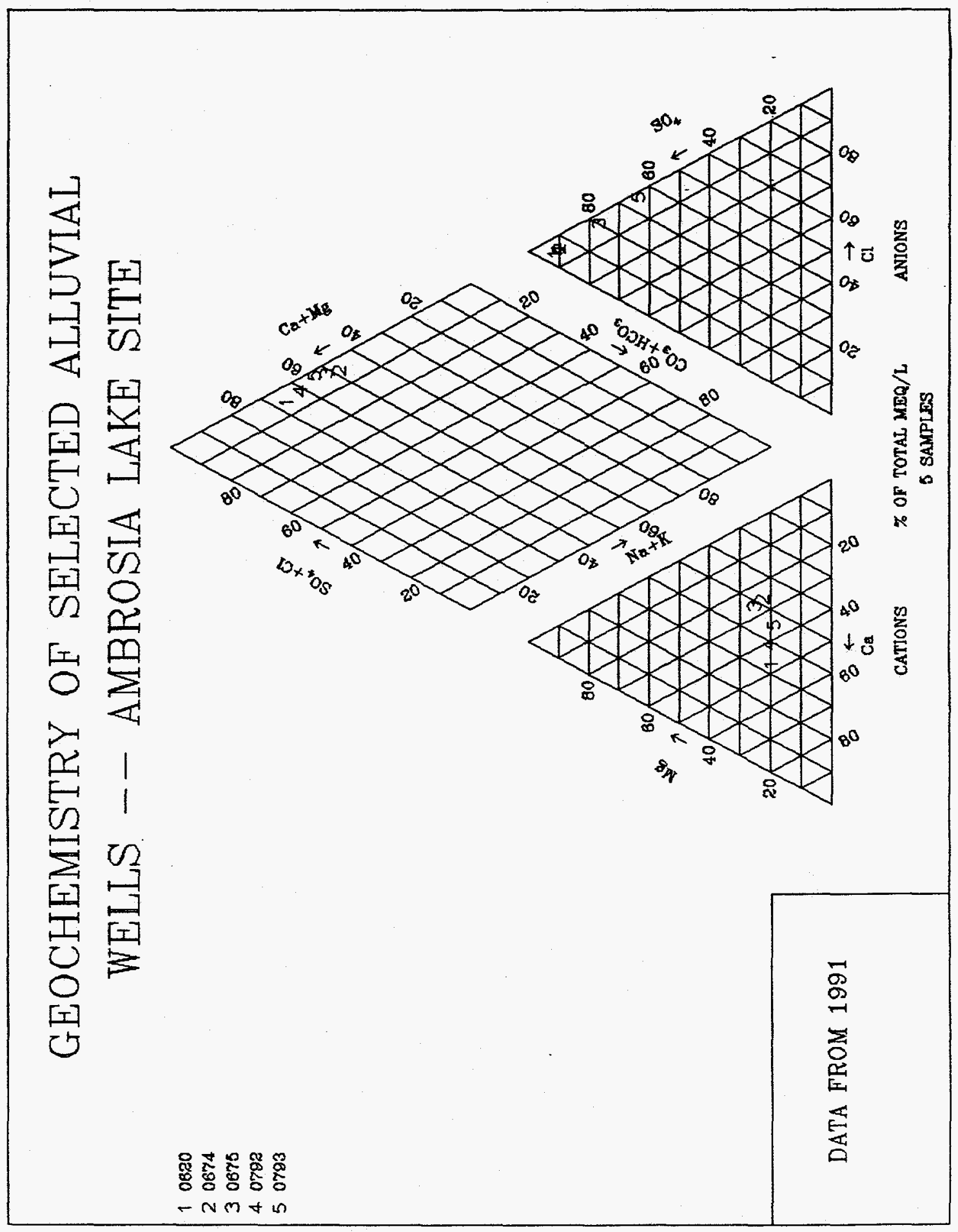




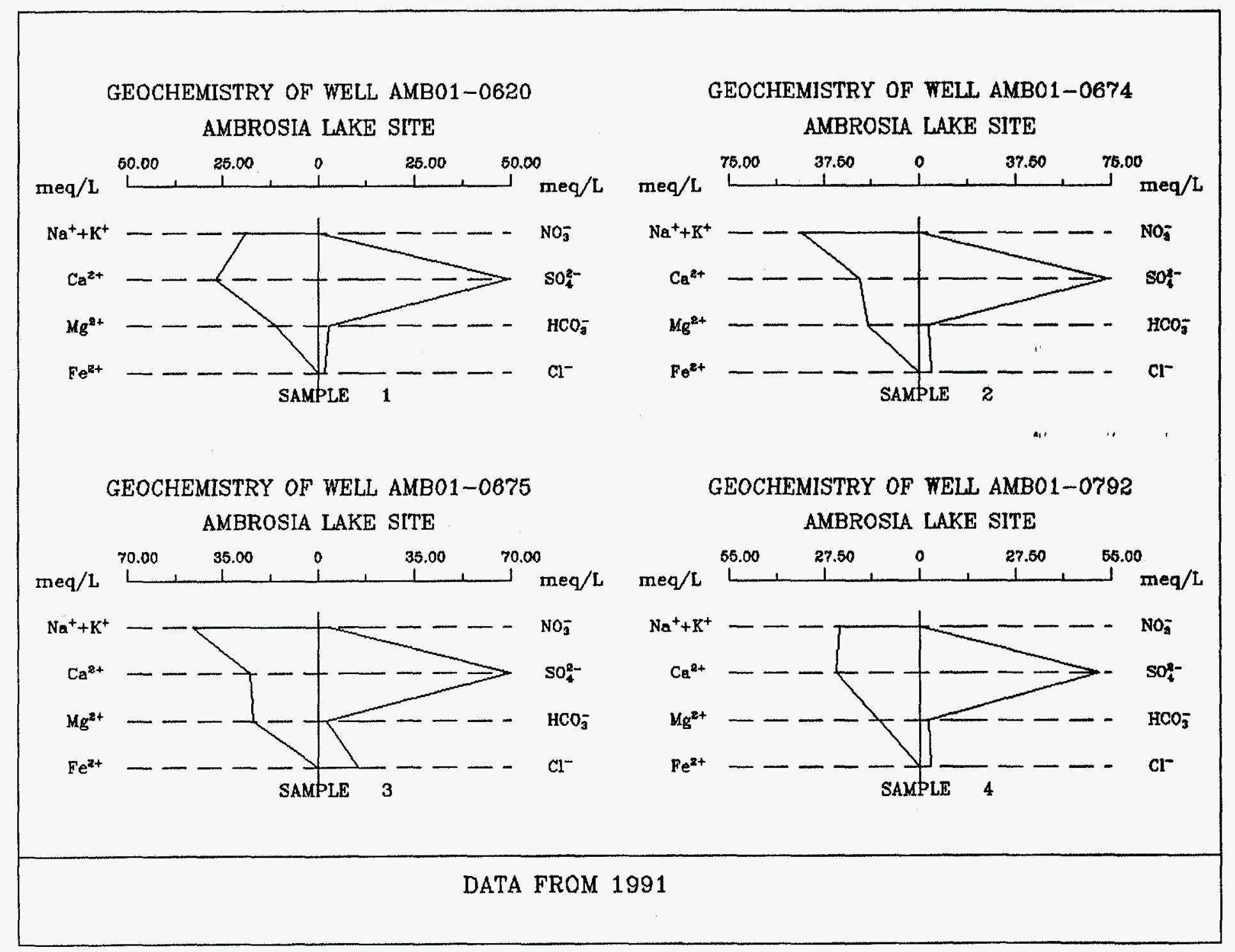




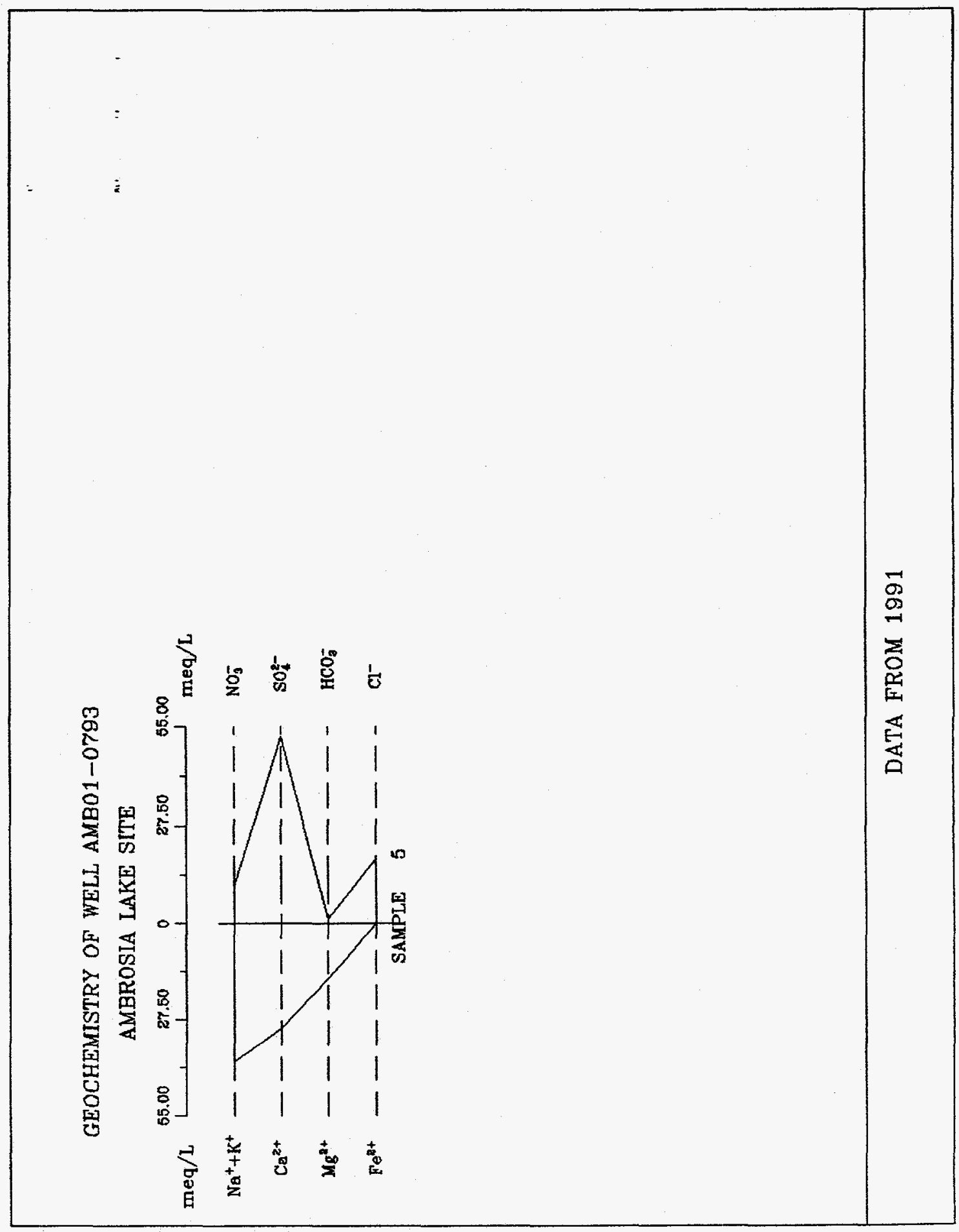




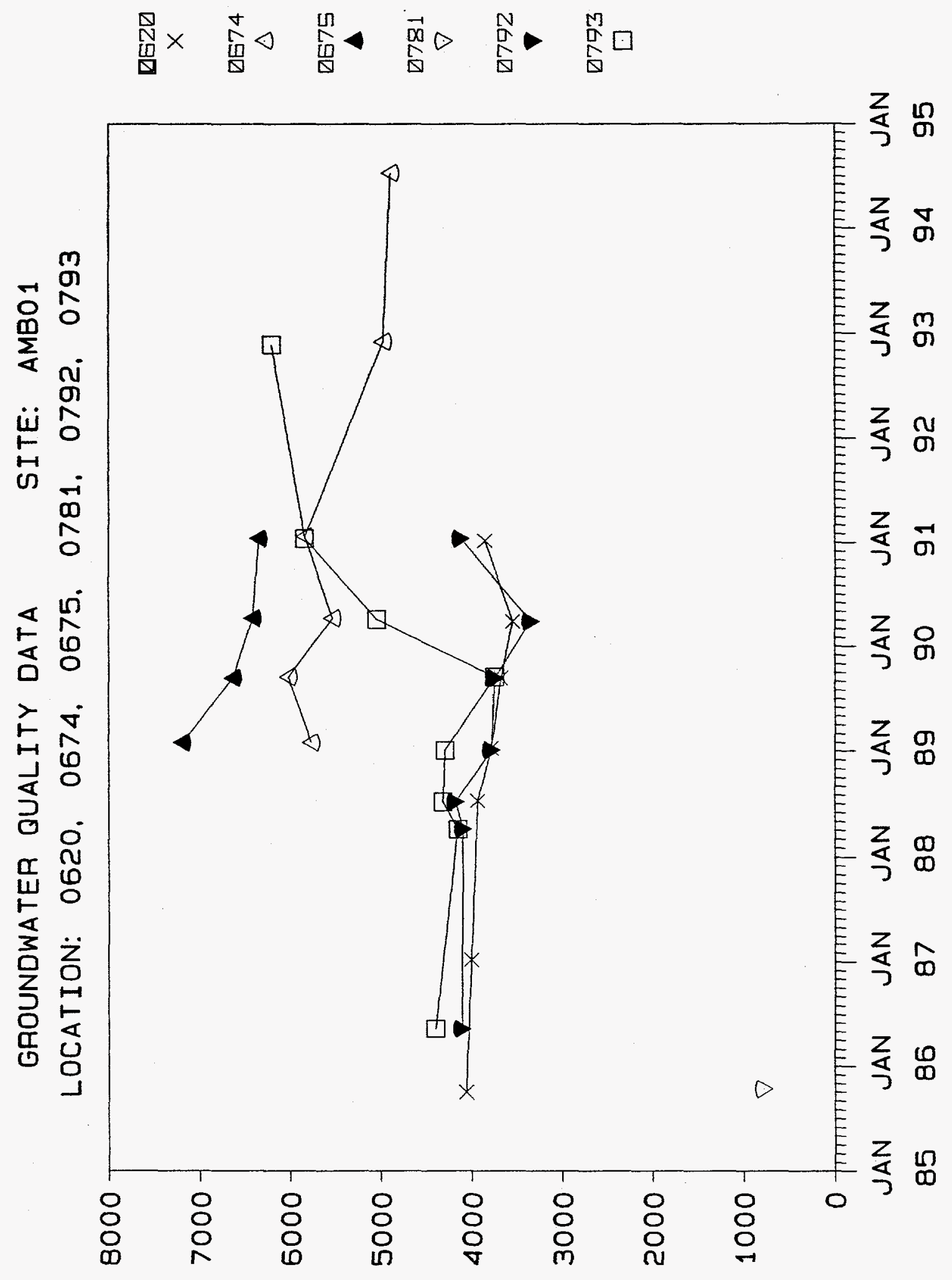

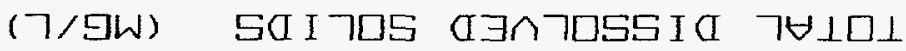




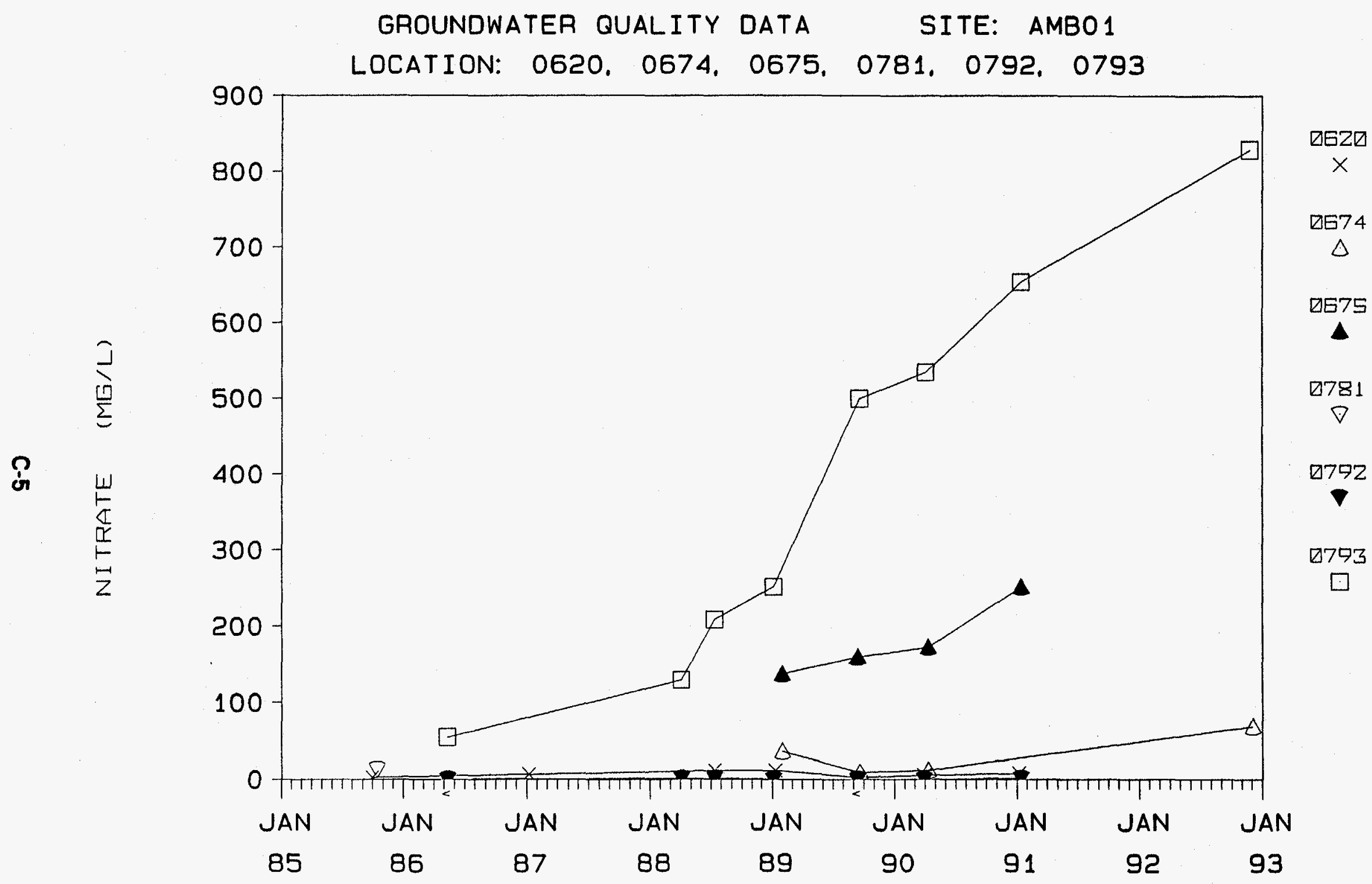




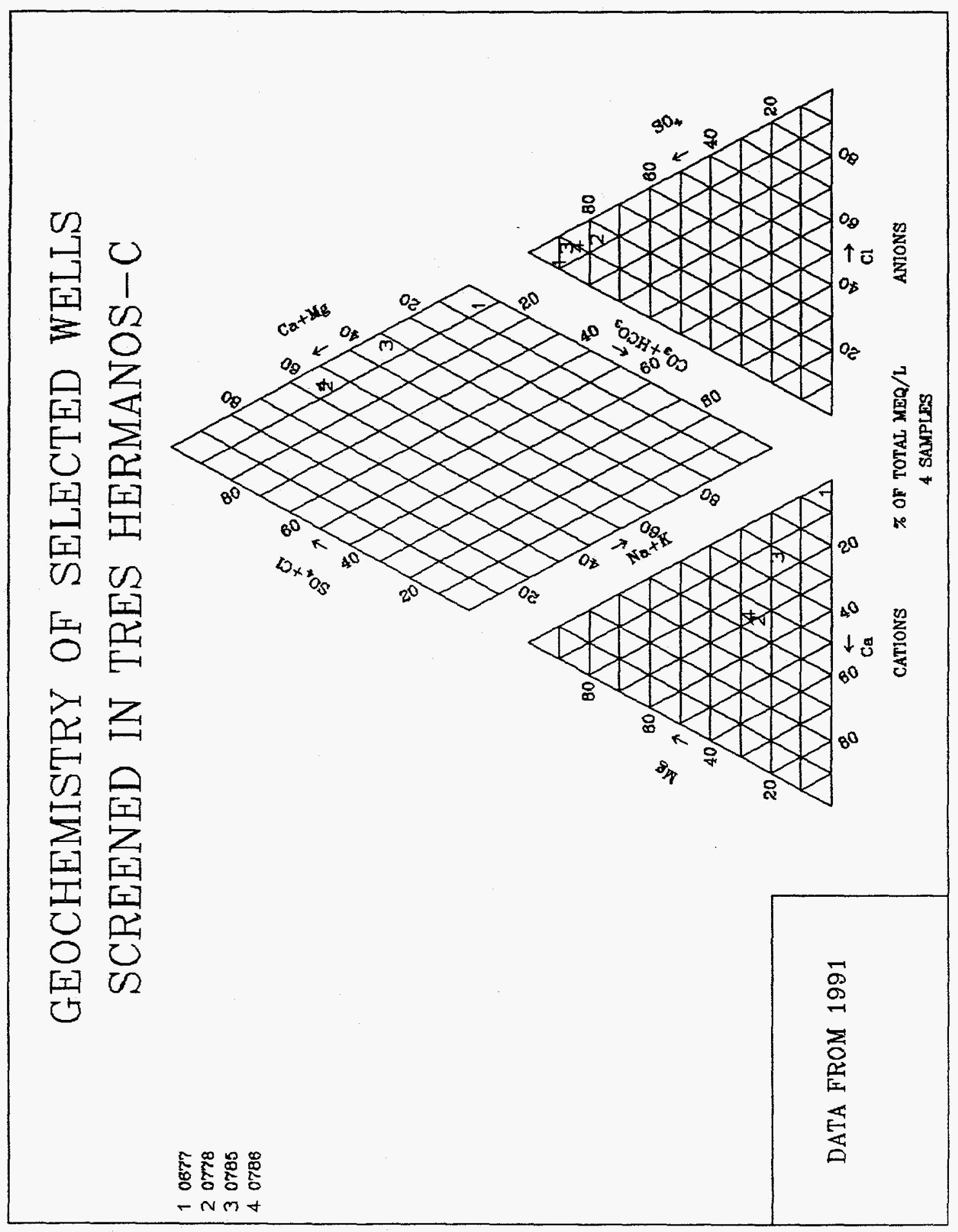




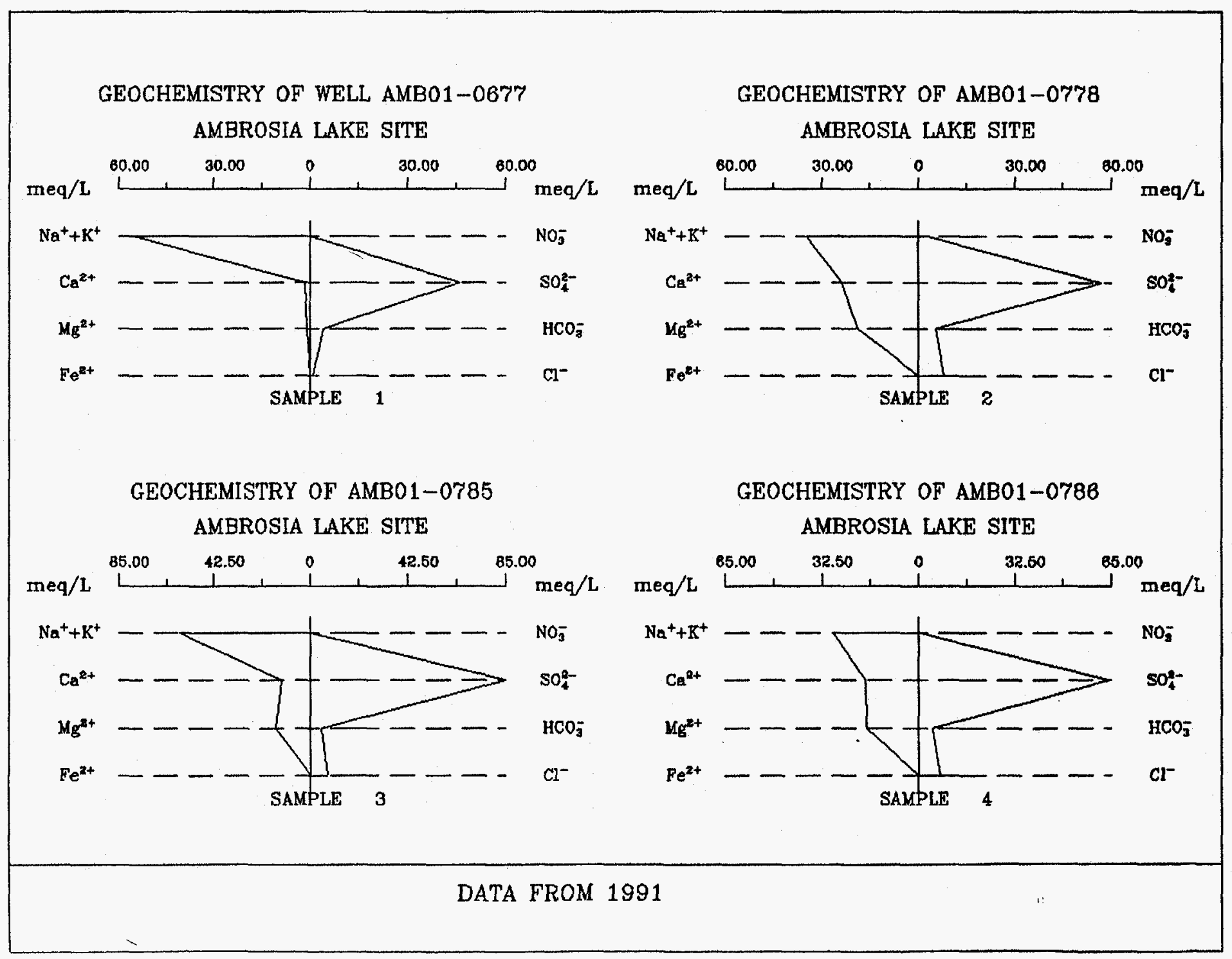




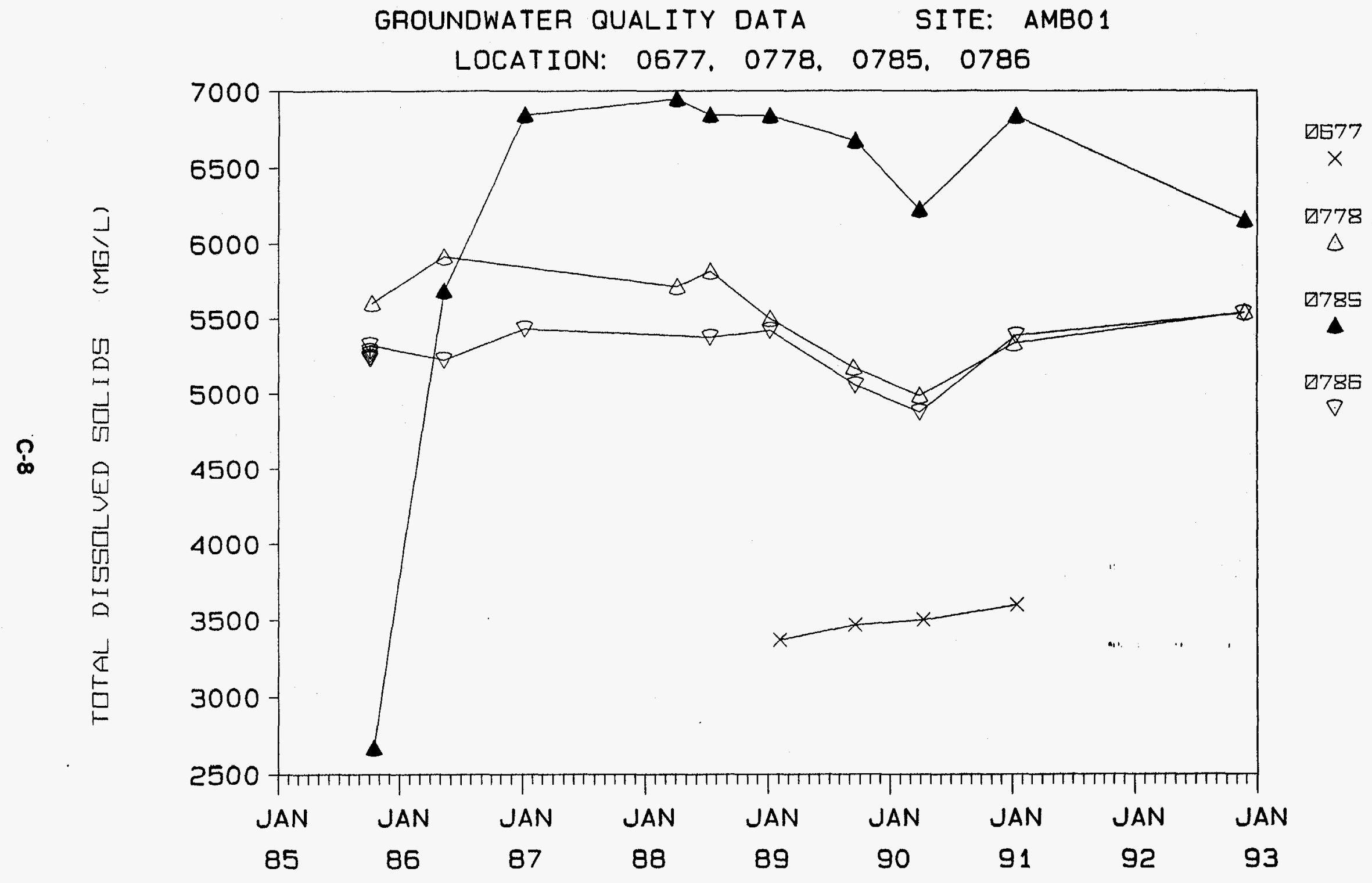




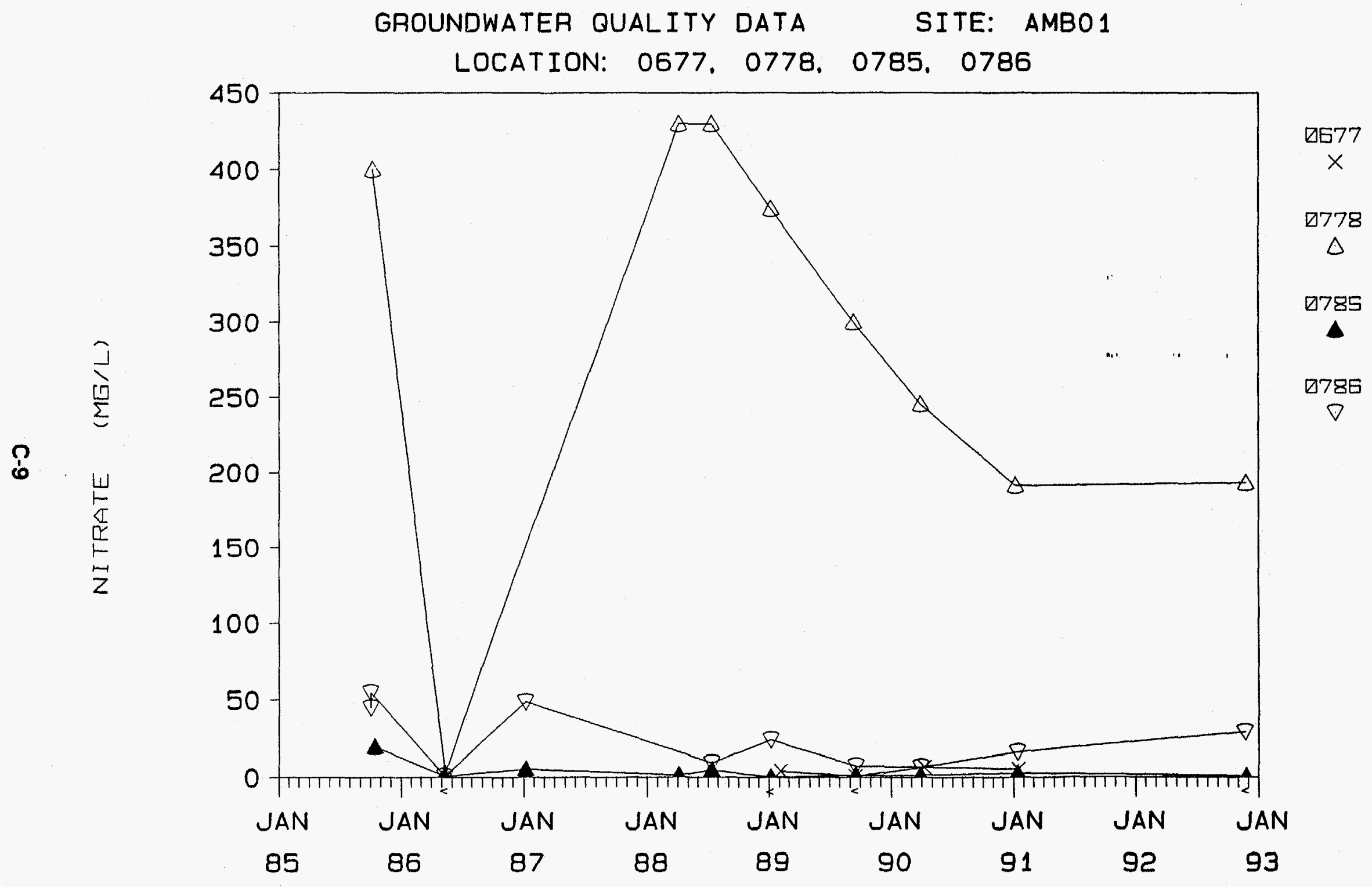




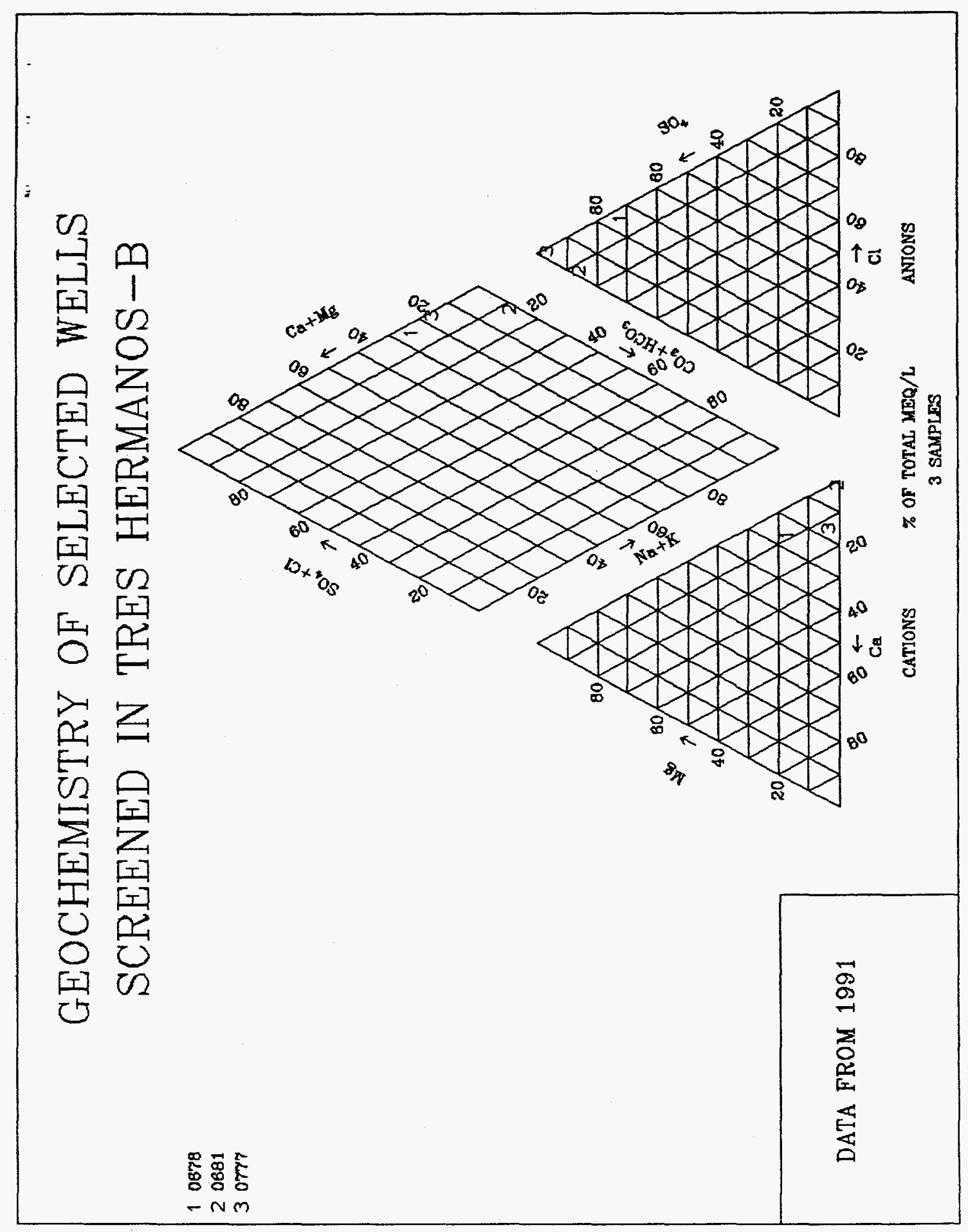




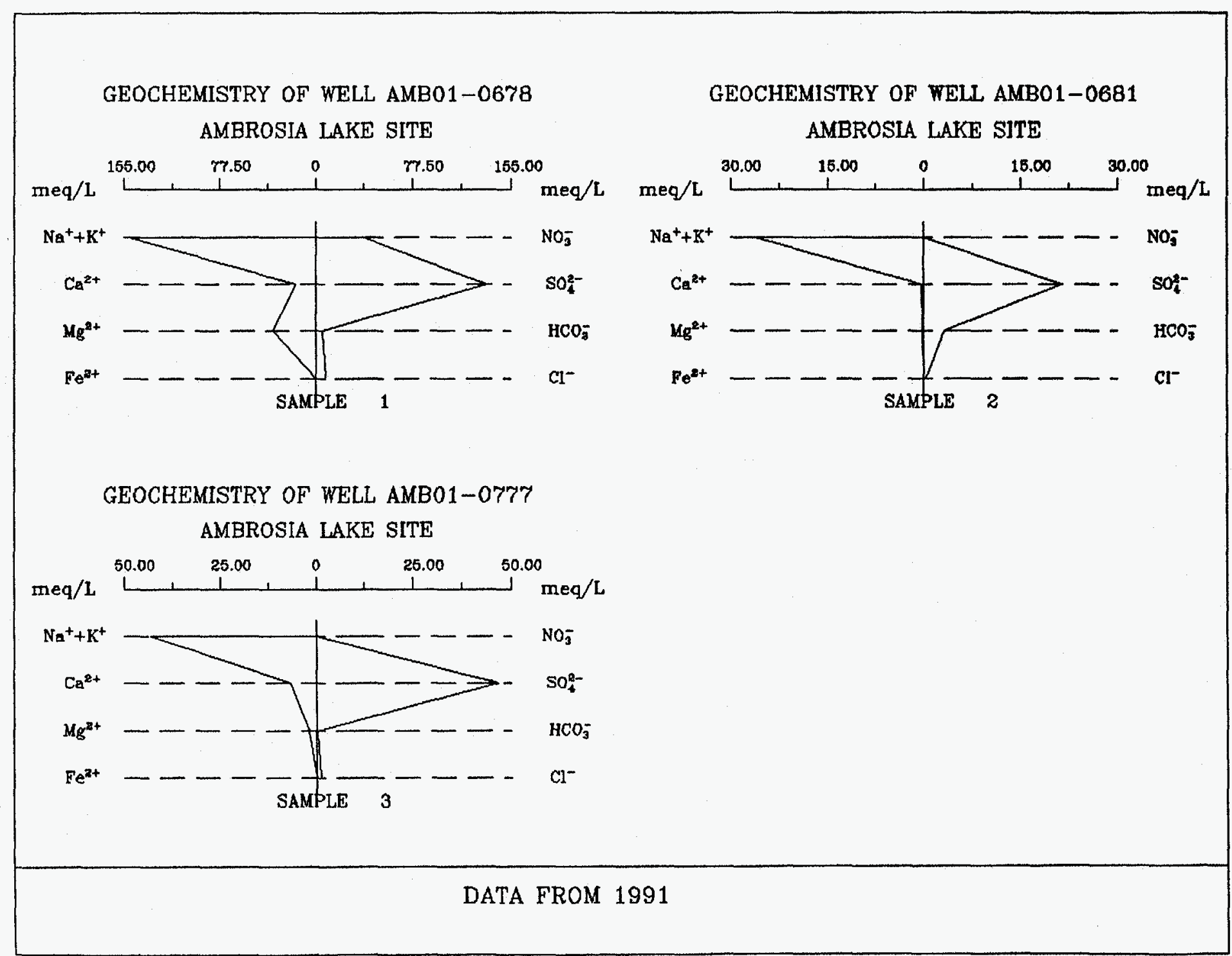




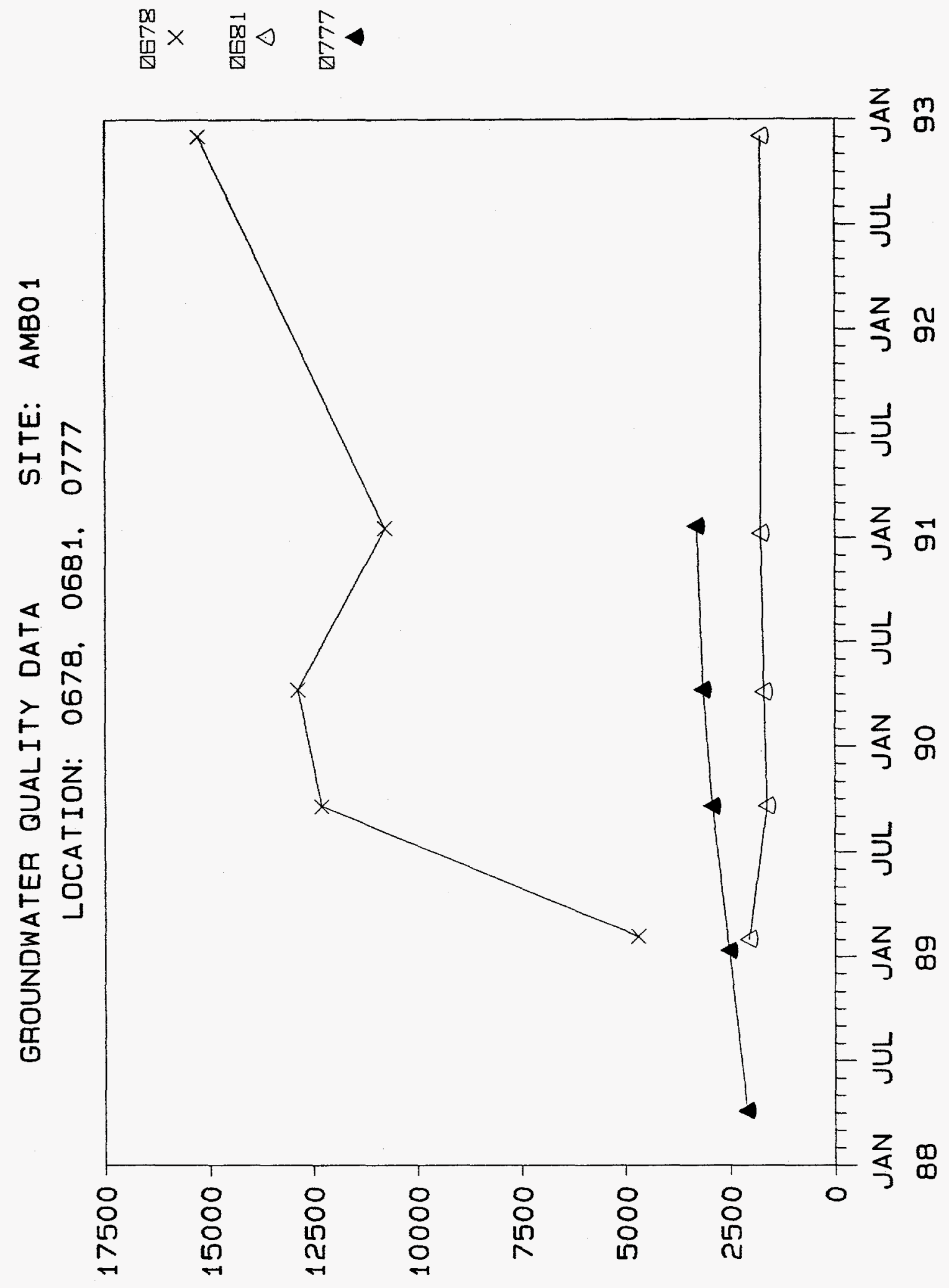

(ᄀ/פW) S匹I 


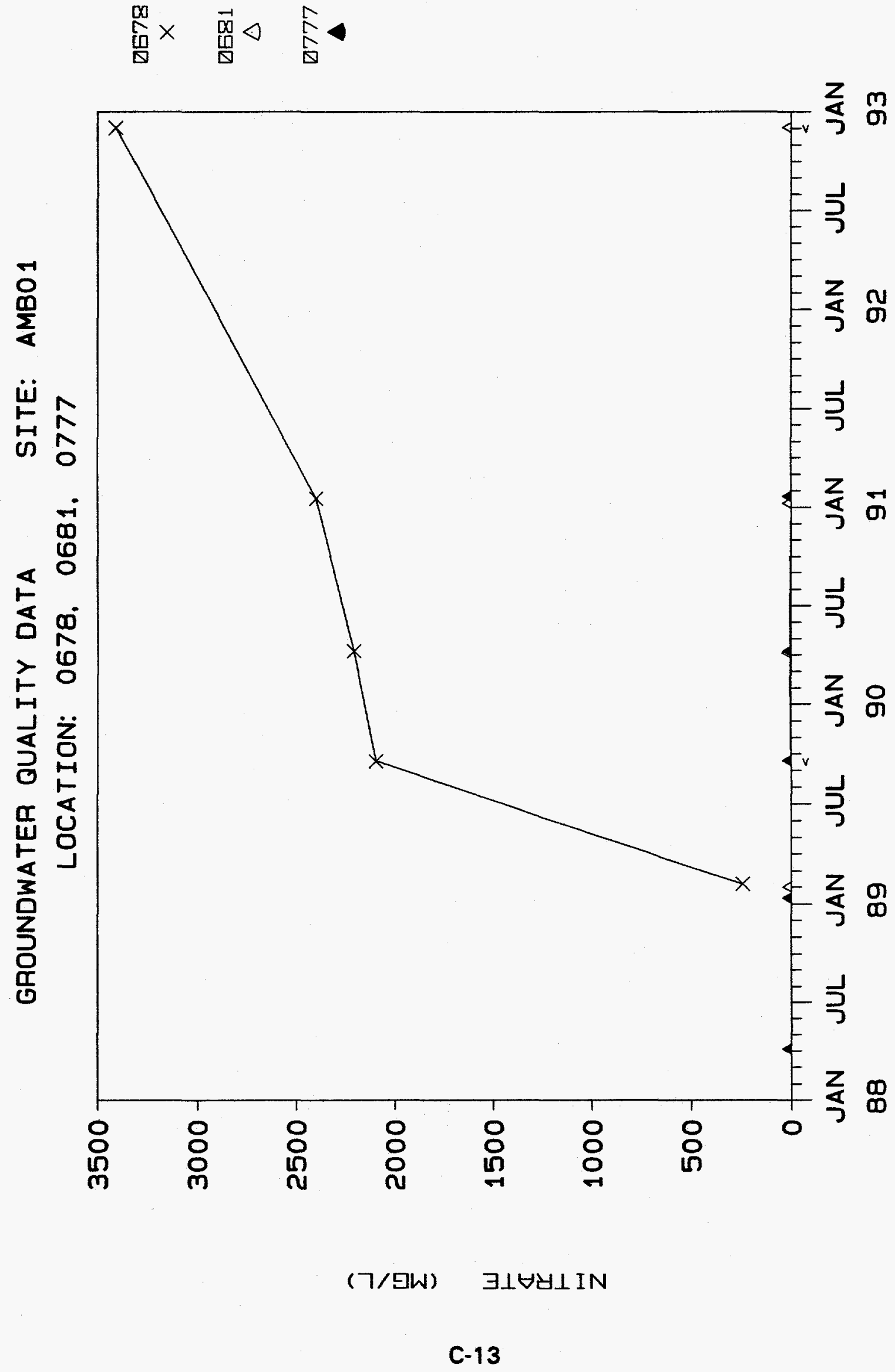




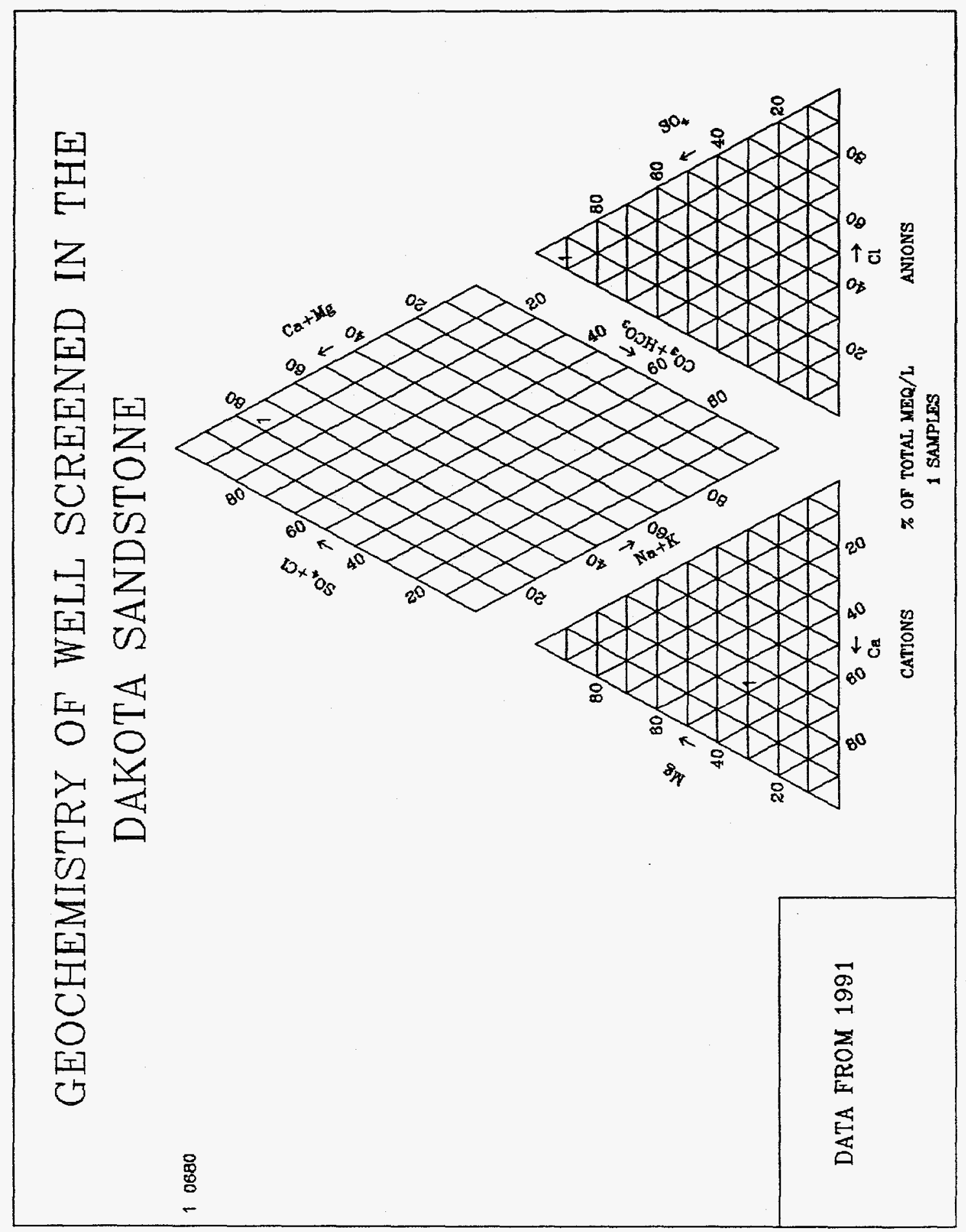




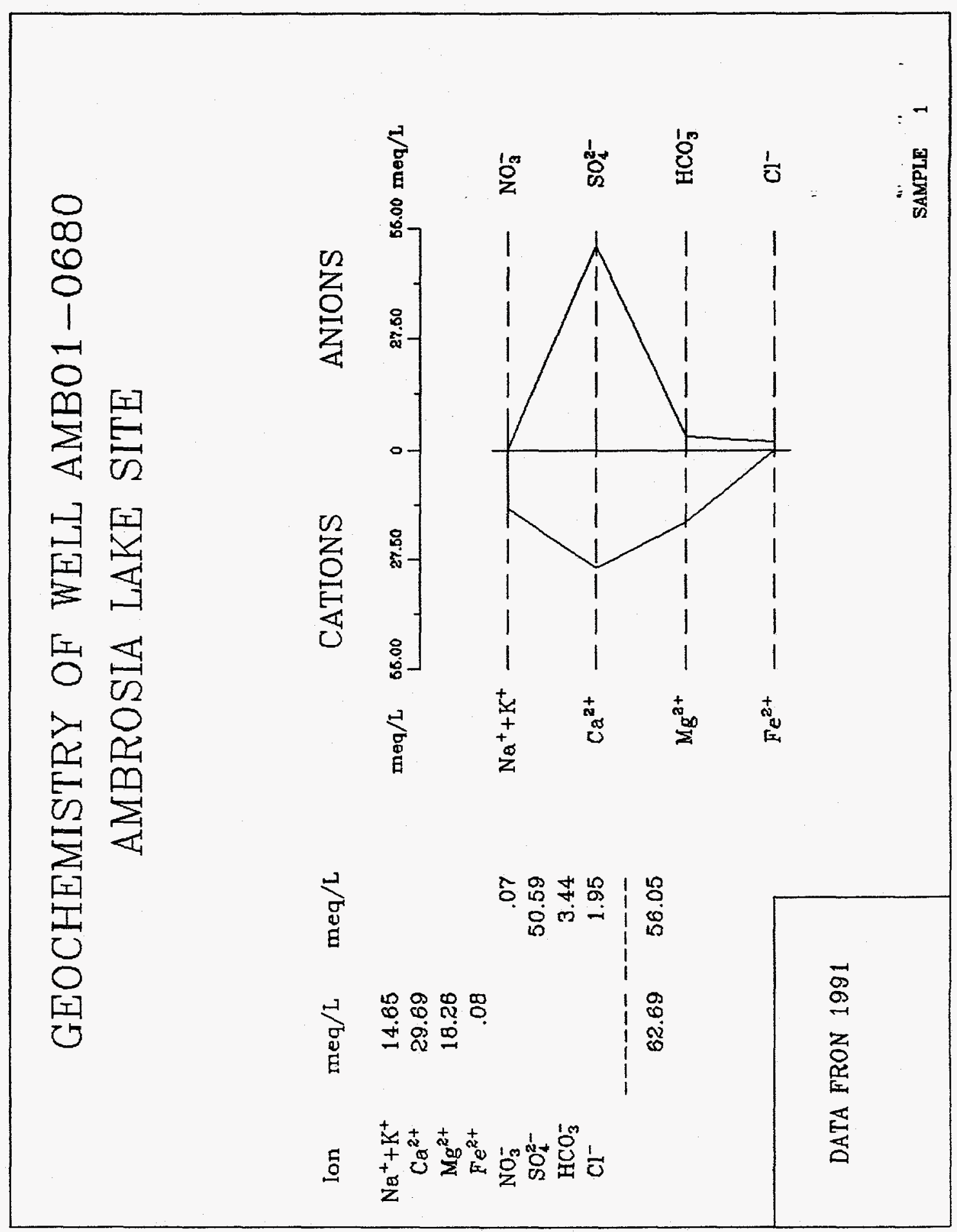




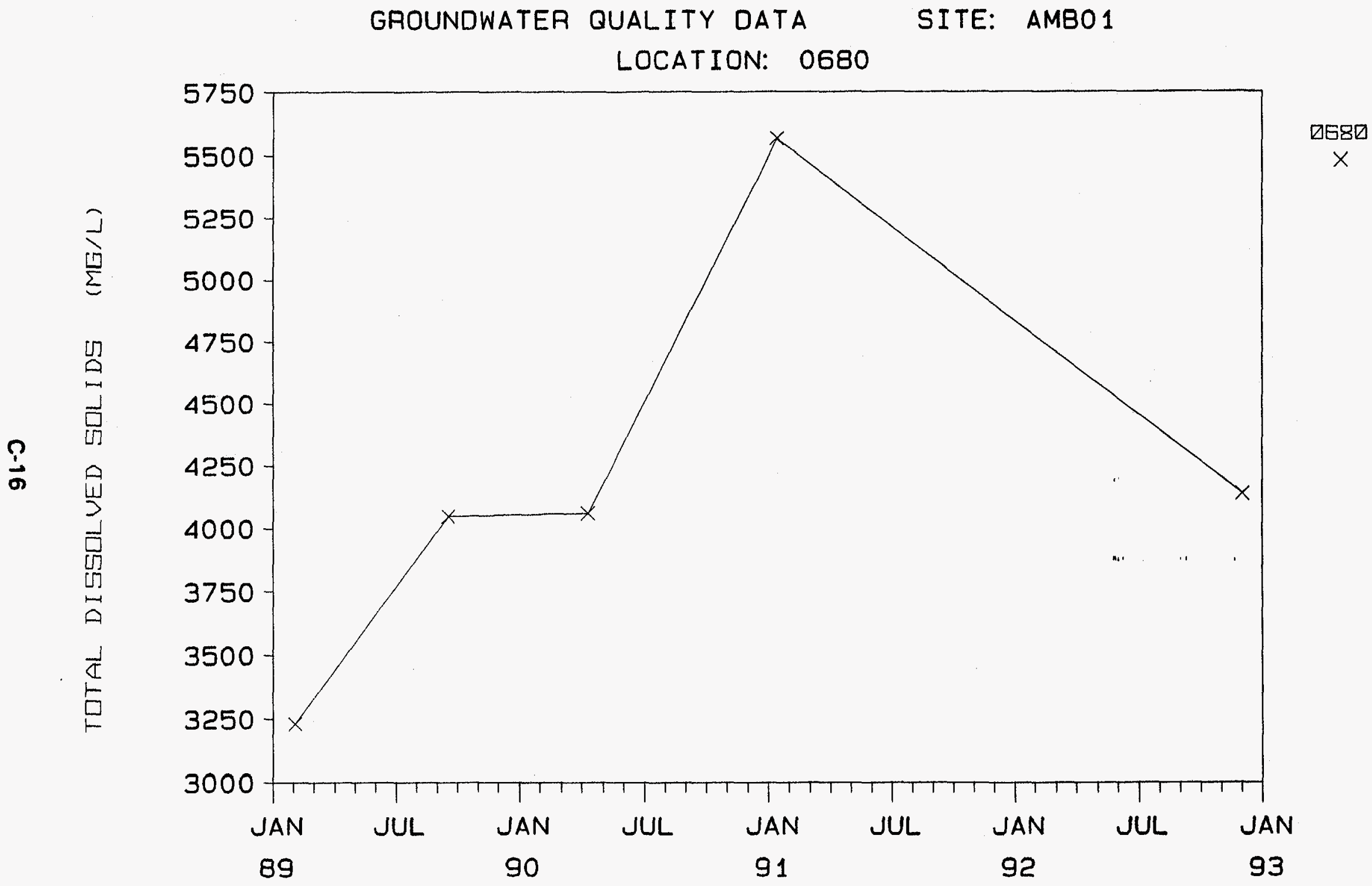




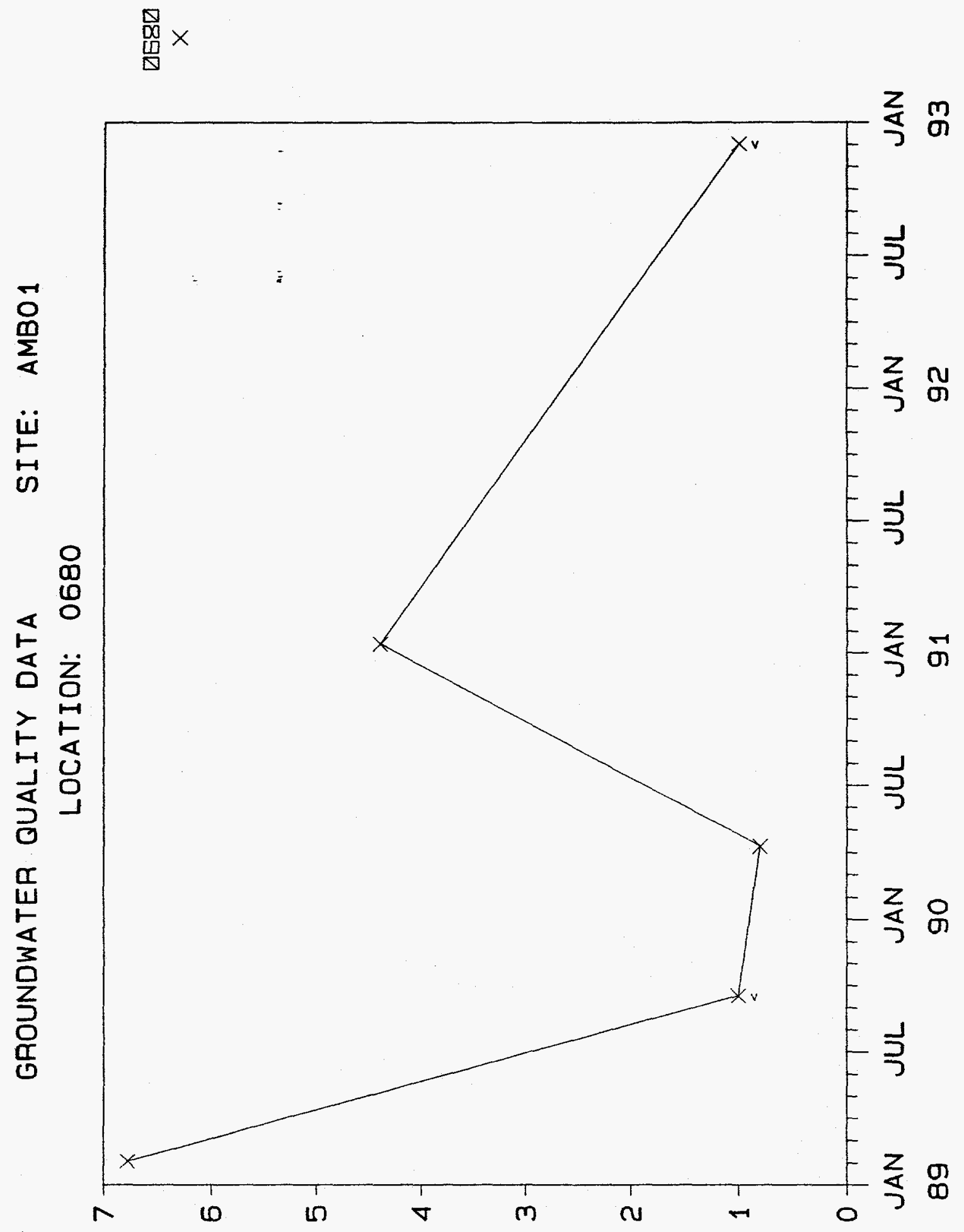

( ᄀ/ロW) $\exists \perp \forall \forall \perp I N$ 